\title{
The cellular response to plasma membrane disruption for nanomaterial delivery
}

\author{
Gaëlle Houthaeve ${ }^{1,2}$, Stefaan C. De Smedt ${ }^{2}$, Kevin Braeckmans ${ }^{2+}$ and Winnok H. De Vos ${ }^{1 *+}$ (1)
}

\begin{abstract}
Delivery of nanomaterials into cells is of interest for fundamental cell biological research as well as for therapeutic and diagnostic purposes. One way of doing so is by physically disrupting the plasma membrane (PM). Several methods that exploit electrical, mechanical or optical cues have been conceived to temporarily disrupt the PM for intracellular delivery, with variable effects on cell viability. However, apart from acute cytotoxicity, subtler effects on cell physiology may occur as well. Their nature and timing vary with the severity of the insult and the efficiency of repair, but some may provoke permanent phenotypic alterations. With the growing palette of nanoscale delivery methods and applications, comes a need for an in-depth understanding of this cellular response. In this review, we summarize current knowledge about the chronology of cellular events that take place upon PM injury inflicted by different delivery methods. We also elaborate on their significance for cell homeostasis and cell fate. Based on the crucial nodes that govern cell fitness and functionality, we give directions for fine-tuning nano-delivery conditions.
\end{abstract}

Keywords: Intracellular delivery, Nanotechnology, Plasma membrane disruption, Cellular homeostasis

\section{Introduction}

Various therapeutic and diagnostic applications demand the introduction of specific nanomaterials into the cell's interior. For instance, in cell-based therapies, the genetic engineering of cells requires the introduction of nucleic acids (e.g., mRNA) and/or proteins (e.g., Cas9 nuclease) into the cytoplasm or nucleus. Labelling of cells, whether it is for fundamental studies or for diagnostic applications, requires intracellular delivery of contrast agents. The plasma membrane (PM) is however impermeable to most of those functional molecules, demanding intracellular delivery technologies. Such methods are broadly classified into carrier-mediated or membrane disruption-mediated approaches. Carrier-mediated approaches rely on the packaging of cargo molecules within a carrier, which enters the cell via endocytosis or by fusion with the PM. The design of the carrier in terms

*Correspondence: Winnok.DeVos@UAntwerpen.be

${ }^{\dagger}$ Kevin Braeckmans and Winnok H. De Vos shared senior authorship

${ }^{1}$ Laboratory of Cell Biology and Histology, Department of Veterinary

Sciences, University of Antwerp, Antwerp, Belgium

Full list of author information is available at the end of the article of size, shape, hydrophobicity, surface charge and surface modifications determines where the cargo will be trafficked to inside the cell. Downsides of carrier-mediated approaches include restricted cargo-carrier combinations, carrier-induced toxicity and overall poor delivery efficiency. Membrane disruption-mediated approaches on the other hand, deliver cargo directly to the cytosol by creating transient pores in the PM. PM permeability is induced mostly by physical stimuli, such as electrical fields, mechanical forces, or light, which can be very well controlled. Intracellular delivery by membrane disruption has the advantage that is a quite universal approach that works independent of the type of cell or cargo molecules. A limitation, on the other hand, is that it is mostly limited to in vitro or ex vivo applications, such as genetic engineering of cell therapy products, while carrier-based delivery is more suited for in vivo therapies.

In the past decade, the field of membrane disruption methods for intracellular delivery has grown exponentially owing to advances in nanotechnology, including the emergence of various nanomaterials and nanofabrication methods [1]. One noteworthy example is the 
combination of nanosensitizers with laser irradiation, which has gained significant interest due to its ability to permeabilize the PM of both adherent and suspension cells with high throughput and spatiotemporal selectivity [2-6]. While most studies on intracellular delivery technologies focus on achieving high delivery efficiencies with minimal acute cytotoxicity, recent studies show that surviving cells can suffer from more subtle effects, such as alterations in morphology and functionality. For example, after permeabilization by a strong electrical field, sustained increases of cell activation markers [7] and loss of cell adhesion proteins [8] have been observed. Therefore, to expedite development of refined intracellular delivery methods based on PM disruption, a deeper understanding is required of how cells respond to and recover from such methods.

In this review, we will first describe the main PM disruption methods used for intracellular delivery. Next, we provide a short overview of the cellular response to PM damage. We then break down the observed cellular effects into the different time scales at which they operate, making a distinction between general effects and those that are specific to a particular type of PM disruption method. Finally, we discuss how these insights may contribute to improving physical delivery methods.

\section{Membrane disruption-mediated techniques for intracellular delivery}

Membrane disruption-mediated techniques perturb the integrity of the PM by generating lesions of different sizes and shapes. Except for pore-forming toxins, all are based on physical stimuli. Here below, we will give a concise overview of the main methods (Fig. 1) and in Table 1 we list their major properties. For a more comprehensive explanation of these techniques, the reader is referred to Stewart et al. (2018).

\subsection{Pore forming toxins}

Many pathogenic bacteria produce cytotoxic proteins that can perforate the membranes of host cells as part of their virulence [9]. The PM is the main target of most pore forming toxins (PFTs), but some PFTs can also perforate intracellular organelle membranes [10]. A distinction is made between $\alpha$-PFTs and $\beta$-PFTs, depending on

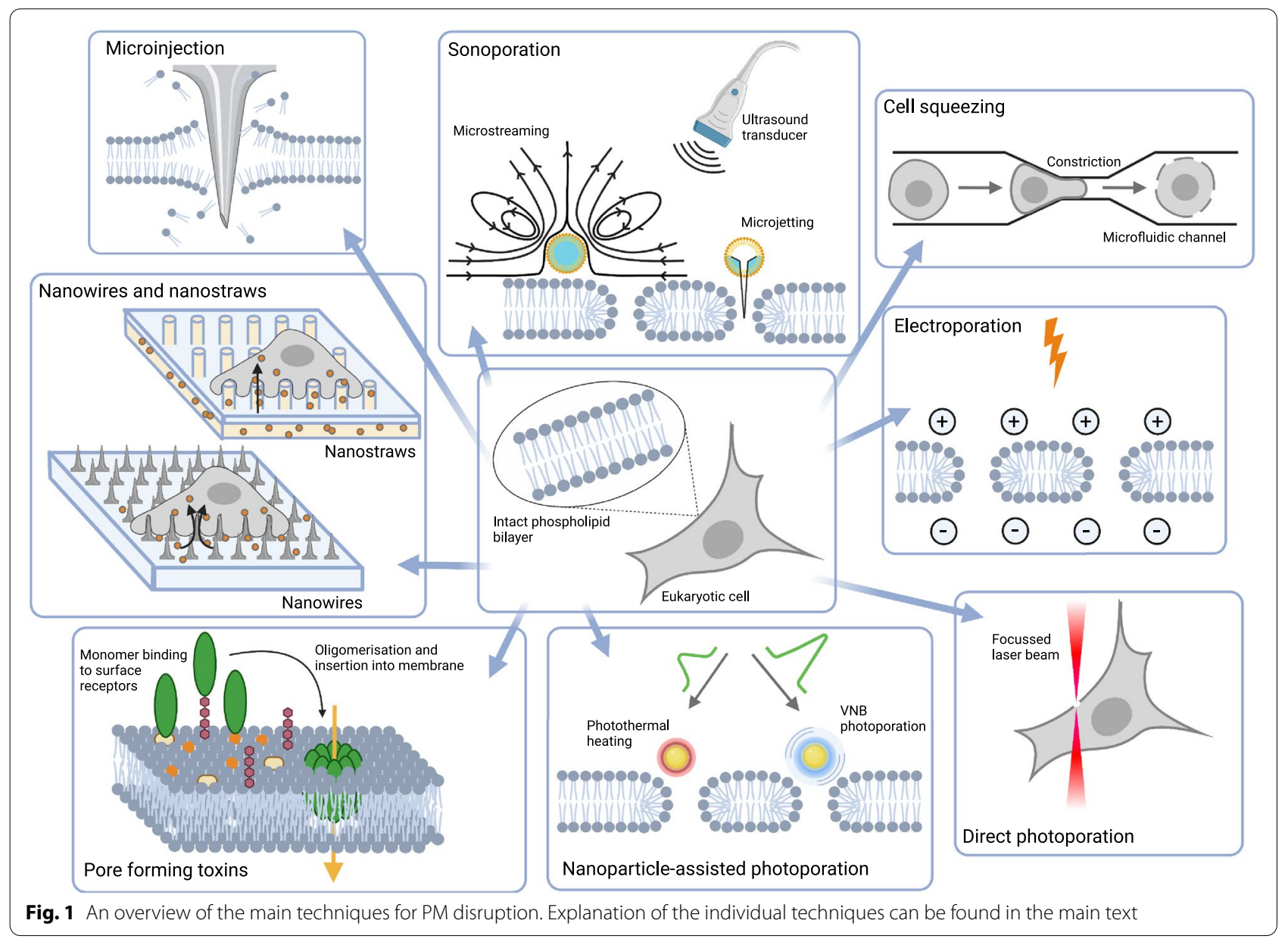


Table 1 Major properties of nanotechnologies for intracellular delivery

\begin{tabular}{|c|c|c|c|c|c|c|c|c|c|}
\hline & Efficiency & Toxicity & Throughput & $\begin{array}{l}\text { Precision at } \\
\text { single cell } \\
\text { level }\end{array}$ & Applicability & Pore size & $\begin{array}{l}\text { Cargo size } \\
\text { that can be } \\
\text { delivered }\end{array}$ & $\begin{array}{l}\text { Mechanisms } \\
\text { of membrane } \\
\text { permeabilization }\end{array}$ & $\begin{array}{l}\text { Documented } \\
\text { cellular } \\
\text { responses }\end{array}$ \\
\hline $\begin{array}{l}\text { Nanow- } \\
\text { ires and } \\
\text { nanostraws }\end{array}$ & Low & Low & High & Medium & $\begin{array}{l}\text { In vitro, ex } \\
\text { vivo }\end{array}$ & $\leq 100 \mathrm{~nm}$ & Several MDa & $\begin{array}{l}\text { Combination of } \\
\text { direct penetration } \\
\text { and stimulated } \\
\text { endocytosis }\end{array}$ & $A, D, E$ \\
\hline $\begin{array}{l}\text { Pore form- } \\
\text { ing toxins }\end{array}$ & High & High & High & Low & In vitro & $15-30 \mathrm{~nm}$ & $\begin{array}{l}\text { Up to } \\
150 \mathrm{kDa}\end{array}$ & $\begin{array}{l}\text { Membrane inser- } \\
\text { tion }\end{array}$ & $A, E$ \\
\hline $\begin{array}{l}\text { Electropora- } \\
\text { tion }\end{array}$ & High & Medium & High & Low & $\begin{array}{l}\text { In vitro, ex } \\
\text { vivo }\end{array}$ & $1-400 \mathrm{~nm}$ & Several MDa & $\begin{array}{l}\text { Formation of } \\
\text { electropores }\end{array}$ & $B, C, F$ \\
\hline $\begin{array}{l}\text { Sonopora- } \\
\text { tion }\end{array}$ & Medium & High & High & Low & In vitro, in vivo & $50-250 \mathrm{~nm}$ & Several MDa & $\begin{array}{l}\text { Different types of } \\
\text { mechanical forces } \\
\text { including shock } \\
\text { waves and shear } \\
\text { stress }\end{array}$ & $A, B, C, E, F$ \\
\hline $\begin{array}{l}\text { Microfluidic } \\
\text { cell squeez- } \\
\text { ing }\end{array}$ & High & Low & High & Medium & $\begin{array}{l}\text { In vitro, ex } \\
\text { vivo }\end{array}$ & ND & $\begin{array}{l}15 \mathrm{~nm} \\
\text { AuNP, QD } \\
\text { and anti- } \\
\text { bodies }\end{array}$ & $\begin{array}{l}\text { Mechanical defor- } \\
\text { mation }\end{array}$ & ND \\
\hline $\begin{array}{l}\text { Direct laser- } \\
\text { induced } \\
\text { photopora- } \\
\text { tion }\end{array}$ & High & Medium & Low & High & In vitro & $80-160 \mathrm{~nm}$ & Several MDa & $\begin{array}{l}\text { A combination of } \\
\text { thermal, mechani- } \\
\text { cal and chemical } \\
\text { effects }\end{array}$ & $A, B, C$ \\
\hline $\begin{array}{l}\text { Nano- } \\
\text { particle- } \\
\text { mediated } \\
\text { photopora- } \\
\text { tion }\end{array}$ & High & Low & High & High & $\begin{array}{l}\text { In vitro, ex } \\
\text { vivo }\end{array}$ & $10-500 \mathrm{~nm}$ & $\begin{array}{l}100-1000 \mathrm{~s} \\
\text { of } \mathrm{kDa}\end{array}$ & $\begin{array}{l}\text { Photothermal } \\
\text { heating, high- } \\
\text { pressure shock- } \\
\text { waves or liquid jet } \\
\text { formation }\end{array}$ & $A, B, C, E$ \\
\hline $\begin{array}{l}\text { PEN photo- } \\
\text { poration }\end{array}$ & High & Low & High & High & $\begin{array}{l}\text { In vitro, ex } \\
\text { vivo }\end{array}$ & ND & $\begin{array}{l}\text { up to } \\
500 \mathrm{kDa}\end{array}$ & $\begin{array}{l}\text { Photothermal } \\
\text { heating }\end{array}$ & ND \\
\hline
\end{tabular}

A, ion fluxes; B, cytoskeletal remodeling; C, morphological changes; D, DNA damage; E, ER stress; F, delay in cell cycle progression; ND, Not Determined

whether their secondary structure consists of $\alpha$-helices or $\beta$-barrels, respectively. In all cases, PFTs recognize the target cell by binding to specific ligands, which can be proteins, lipids or sugars. Oligomerization of most $\alpha$-PFT monomers occurs concomitantly with their insertion into the plasma membrane, while most $\beta$-PFTs first form a pre-pore that undergoes conformational rearrangements at cell surface receptors, subsequently leading to their insertion in the membrane [11]. A main group of PFTs that has been exploited for intracellular delivery are the cholesterol-dependent cytolysins produced by Gram-positive bacteria. This family of PFTs allows the formation of pores with a diameter of 25 to $30 \mathrm{~nm}$ [12]. Streptolysin O has been used most in vitro [13-15] and allows the delivery of molecules up to $150 \mathrm{kDa}$ [15].

\subsection{Direct membrane penetration}

PM disruption through direct penetration involves the use of a conduit or vehicle to stab through the membrane. The oldest and best-known example is microinjection, in which the cell membrane is punctured with a miniaturized pipette through which a defined volume of fluid containing the cargo can be injected into the cell. The technique allows delivery of large cargo up until several MDa such as plasmid DNA [1618]. To increase precision, nanoneedles (or nanowires) have been developed with shorter lengths $(<1 \mu \mathrm{m})$ and thinner tips $(<100 \mathrm{~nm})$. This allows injecting compounds even in small subcellular compartments [19]. Arrays of vertically aligned nanowires have been fabricated as well, allowing thousands of cells to be permeabilized simultaneously. Although some reports claim that cells become spontaneously permeabilized by culturing them onto such nanowire arrays [20, 21], others have shown that they enhance endocytic uptake $[22,23]$. Still others find that permeabilization only happens when cells are forcefully pushed onto the needles, e.g., by centrifugation [24, 25]. Regardless of the precise mechanism, intracellular delivery is achieved by adding cargo to the medium or by coating the cargo onto nanowire tips [26, 27]. Alternatively, cargo can be pumped through nanostraws, hollow versions of nanowires, thus enhancing delivery efficiency $[28,29]$. 


\subsection{Electrical membrane permeabilization}

Electrical membrane permeabilization, or electroporation in short, is an approach in which high-intensity and low frequency electrical pulses are used to temporarily destabilize the PM $[30,31]$. Transient disruptions in the PM allow the entry of extraneous molecules into the cytoplasm. While smaller molecules can enter by simple diffusion, the entry of macromolecules with a high charge density such as nucleic acids is facilitated by active electrophoresis as well. The dimension and distribution of the created pores typically depend on the magnitude and duration of the applied electric fields [32]. For reversible electroporation, several parameters such as field strength, pulse duration and number of pulses need to be carefully selected to preserve cell viability. If the pulse duration and applied field strength prevent the cell from restoring its integrity, disturbance of the electrolyte balance may trigger cell death $[33,34]$. Each cell type demands an optimized electroporation protocol [34, 35], but once determined, up to millions of cells can be treated simultaneously. However, the strong electric fields used in current electroporation techniques may still lead to significant damage or death to cells [36, 37].

\subsection{Sonoporation}

Sonoporation induces the formation of transient PM pores through acoustic pressure waves, mostly in the ultrasound frequency range $(20 \mathrm{kHz}$ to $\mathrm{GHz})$ [38]. The two main mechanisms by which sonoporation perturbs the PM are assumed to be stable cavitation and inertial cavitation (bubble implosion), but other mechanisms have been reported as well $[39,40]$. While stable cavitation induces PM disruption through local oscillatory shear forces generated by microstreaming [41, 42], inertial cavitation punctures the membrane via more extreme phenomena, such as potent fluid shear forces generated by microjetting $[43,44]$. The addition of gas body ultrasound contrast agents has been shown to drastically improve transfection efficiency compared to ultrasound alone, as they act as cavitation nuclei [45]. A major issue is the random and uncontrolled nature of cavitation events that lead to relatively high levels of cell damage and death [46]. Nevertheless, sonoporation has been shown to hold potential for in vivo applications, where barriers for delivery of therapeutic cargo are situated at the tissue level rather than the cellular level [47].

\subsection{Microfluidic cell squeezing}

Any shear force induced by severe mechanical deformation may also transiently permeabilize the PM. An elegant implementation drives cell suspensions through a narrow constriction in a microfluidic channel, which causes their rapid mechanical deformation [48]. The constriction volume is tuned to the size of the cells to achieve transient disruption of the PM, which in turn enables the intracellular passage of macromolecules present in the surrounding buffer [49-51]. The PM recovers in a matter of minutes, after which the macromolecules remain trapped in the cytoplasm. While it can operate with very high throughput ( $\sim$ million cells per second) and has been shown to minimally perturb cell viability and functionality [52], the method is obviously limited to cells in suspension. A practical difficulty is that cells clog at the constriction sites [53]. Moreover, as different cell types differ in size, each cell type requires the development of a new microfluidic device with an optimized constriction volume [54].

\subsection{Direct laser-induced photoporation}

In direct laser-induced photoporation, also termed optoporation, permeabilization is achieved via the direct interaction of a focused laser beam with the PM. Typically, high-intensity femtosecond (fs) laser pulses are employed [55-57]. Membrane pores can be created through photothermal, photomechanical, and photochemical processes and the contribution of each of these processes to membrane poration depends on the laser wavelength, intensity and pulse duration [60-62]. Entry of cargo molecules through the pores occurs by simple diffusion. Even plasmid DNA has been delivered this way with very high transfection efficiency and cell viability [58]. Notwithstanding its effectiveness for single-cell transfections, the general utility has been questioned due to the labor-intensive procedure, high cost and low throughput $[58,59]$. On the other hand, via careful $3 \mathrm{D}$-focusing of the focal volume onto the structure that needs to be permeabilized, even intracellular structures such as the nuclear envelope can be specifically perturbed, while leaving the PM intact [60].

\subsection{Nanoparticle-mediated photoporation}

To enhance throughput and efficiency of direct laserinduced photoporation, the process has been combined with photothermal nanoparticles (NPs). Gold NPs (AuNPs) are used most frequently [2, 3, 61], but other sensitizing particles such as graphene quantum dots [62] and iron oxide-based NPs [5] are bonafide alternatives. Transient permeabilization of the PM is generally achieved by incubating cells with the NPs. After washing away non-associated NPs, the cargo of interest is added and cells are irradiated with a laser, hereby forming pores in the PM at the places where the NPs are present. By using photothermal NPs, the laser energy density needed to create pores is vastly reduced as compared to direct laser-induced photoporation. Consequently, rather than a focused laser beam (as for optoproation), a wide laser 
beam can be used, which enhances throughput from a few cells per minute to 100.000 cells per second [63]. PM permeabilization is achieved by a variety of photothermal mechanisms that depend on the laser energy and fluence. Upon absorption of continuous wavelength laser light or low intensity laser pulses, the temperature of the NPs increases by tens to several hundred degrees Celsius. The generated heat diffuses into the surrounding environment and causes permeabilization of the nearby PM by a local phase transition of the lipid bilayer or thermal denaturation of integral glycoproteins [64]. Both phenomena result in the formation of short-lived pores with sizes ranging from tens to hundreds of nanometers, depending on the NP size and laser intensity. When the NPs are irradiated with sufficiently high laser fluences, usually from high energy pico- or nanosecond pulsed lasers, the temperature of the NPs can exceed the surrounding liquid's critical temperature. This results in the vaporization of the liquid around the NPs, leading to the formation of vapor nanobubbles (VNBs). A VNB expands until the thermal energy from the heated NP is consumed [65], after which it collapses and induces mechanical shock waves that generate transient pores in the adjacent membrane. VNB photoporation has been reported to allow intracellular delivery of various compounds, ranging from fluorescent markers $[2,4,66]$, over RNA-based macromolecules $[2,3,67,68]$ and plasmid DNA [69, $70]$ to proteins $[71,72]$. Moreover, it can do so in both adherent and suspension cells with high efficiency and low cytotoxicity $[3,66,69,73]$ and it has the precision to target organelle membranes such as the nuclear envelope [74]. Instead of adding photothermal NPs to cells, it is also possible to integrate photothermal features into substrates onto which cells can be cultured [75-77]. This has the advantage that the nanosensitizers will not be ingested by the cell, thereby eliminating a potential safety issue for clinical translation.

\section{Time-dependent responses to plasma membrane injury in a nutshell}

By physically separating the cellular interior from the extracellular environment, the PM creates a biochemically unique environment. Dedicated pumps and transporters tightly control molecular traffic across the PM ensuring a meticulously titrated content. Hence, even the smallest disruptions of the PM barrier can affect cell homeostasis and cell viability. Nanometer-sized ruptures in the PM reseal spontaneously in vitro [78, 79], while closure of larger holes is hampered by membrane tension arising from a combination of intracellular osmotic pressure and cytoskeletal tension (reviewed in [80]). For their sealing, cells rely on active repair machinery (Fig. 2). The instant response to PM disruption is an influx of $\mathrm{Ca}^{2+}$, which induces rapid depolymerization of the underlying cortical actin cytoskeleton. The subsequent repair involves the activation of several $\mathrm{Ca}^{2+}$-responsive proteins (extensively reviewed in [81]). Irrespective of the size of the PM breach, initial resealing occurs within $30 \mathrm{~s}$ $[82,83]$. Proteins of the annexin family form a plug [84, $85]$ and facilitate closure of small $(\mathrm{nm})$ lesions through membrane constriction [86, 87]. Sealing of larger lesions (up to micrometers) relies on fusion of cytoplasmic vesicles with the PM at the injury site (patching) [85, 88-90].

Once the injury site is closed, the resealed PM and the underlying cytoskeleton must be restored to their prerupture state. For instance, in oocytes and early embryos PM restoration and cytoskeletal repair are intimately linked via the formation and contraction of an actomyosin ring (AMR) minutes post-injury [91]. In somatic mammalian cells on the other hand, there is no such mechanism, and repolymerization of the cortical actin cytoskeleton starts as soon as the PM integrity is reestablished (between 10 and $40 \mathrm{~s}$ after disruption [92]). Membrane remodeling to the pre-rupture state takes 60-240 s post-injury [82, 93], or sometimes longer [94]. This includes active removal of damaged membrane, which in the case of small disruptions occurs either by endocytosis [95-97] and/or by pore shedding [98-100]. Exocytosis of endomembrane vesicles at sites adjacent to the injury site probably serves to facilitate tension relief [101-103] and further aids in membrane repair by bringing the membrane edges closer together. Fusion of endomembranes with the PM can replenish lipids and proteins lost at the injury site [94]. For a more comprehensive overview of the various mechanisms of plasma membrane repair, the reader is referred to excellent reviews on this topic [104, 105].

The consequences of PM disruption do not end with its repair. Cells aim at restoring intracellular homeostasis as well. To do so, they activate several time-dependent processes (Fig. 3). Excessive levels of $\mathrm{Ca}^{2+}$ and reactive oxygen species (ROS) [81] need to be eliminated from the cytoplasm, while cell components that were expelled during PM disruption, such as ions and ATP [106, 107], are to be recovered. Similarly, intracellular macromolecules (lipids, DNA or proteins) that are damaged directly (e.g., through heating) or indirectly (e.g., through ROS) during PM injury must be repaired or removed. To prioritize energy consumption for these restorative processes and to avoid transmission of damage to the progeny, cells will trigger an arrest in cell cycle progression $[108,109]$ and/or translation [110, 111]. If successfully restored, cells will resume their normal functioning, but sustained activation of transcription factors (e.g., CREB) and/or persistent molecular damage may induce lasting changes in gene expression programs and alter cell fate. 


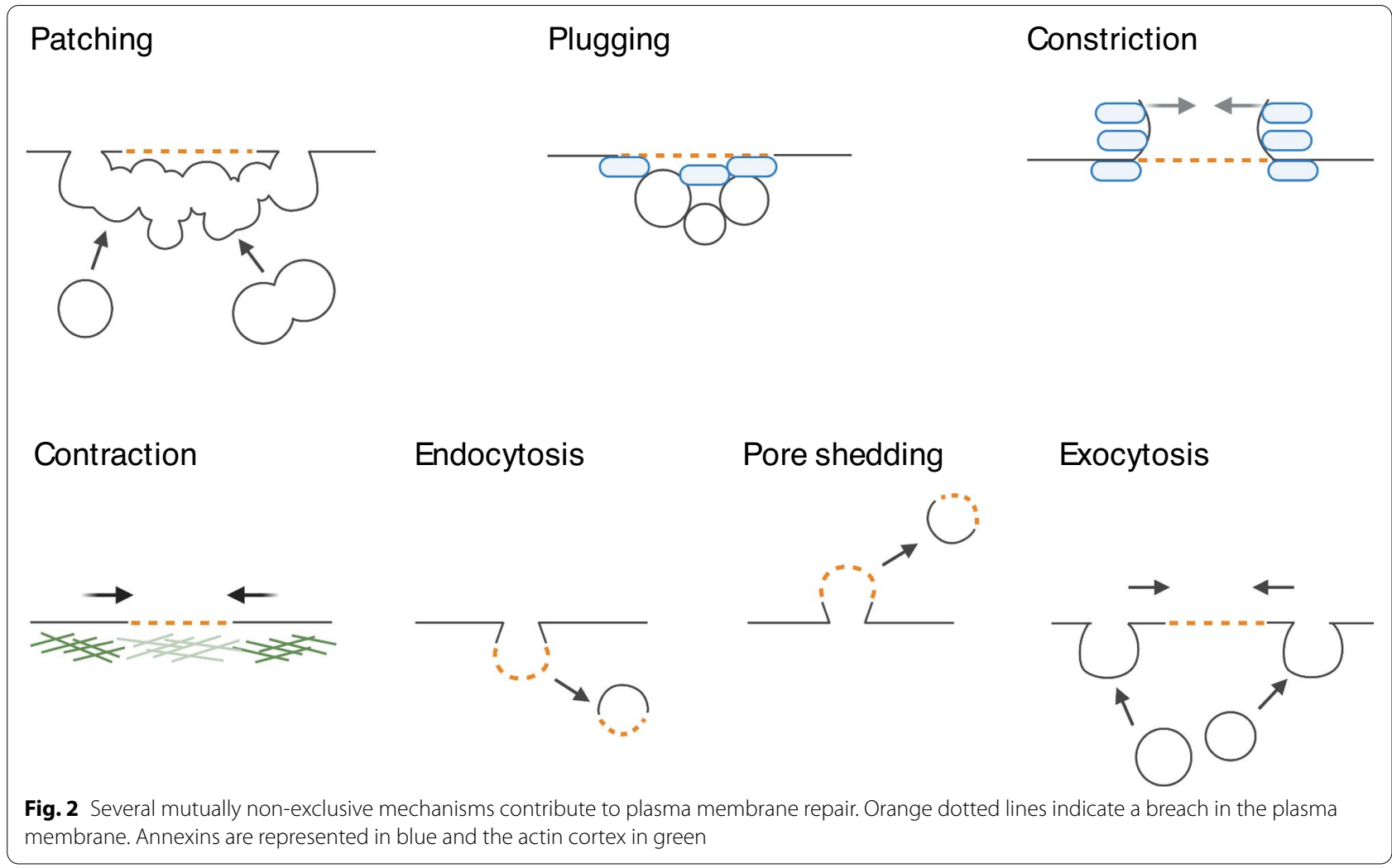

Some will facilitate adaptation of the cell, to allow it to withstand a subsequent injury, while others evoke phenotypic changes of which the functional relevance is not yet known. In the following sections we will go deeper into the exact molecular rearrangements that take place at the short, mid- to long-term, and give examples of which processes have been documented for nanodelivery techniques.

\section{A breach in the PM is rapidly repaired but may cause molecular damage and morphological remodeling}

4.1 Instant molecular fluxes and their reversal

Disruption of the PM provokes an instantaneous influx of ions, among which $\mathrm{Ca}^{2+}$, which is required for efficient repair $[112,113]$. When reaching a critical threshold, additional $\mathrm{Ca}^{2+}$ may be released from intracellular stores such as the endoplasmic reticulum or the lysosomes [114-116]. $\mathrm{Ca}^{2+}$ influx has been documented for various delivery techniques including sonoporation [117, 118], optoporation [116] and nanoparticle-sensitized photoporation [119]. For optoporation, it was shown that the time for reaching the critical threshold level for intracellular $\mathrm{Ca}^{2+}$ release, scaled inversely with the pore size and opening time [116]. For nanoparticle-sensitized photoporation, intracellular stores were found to be the primary source of cytosolic $\mathrm{Ca}^{2+}$ increase [119].

Next to $\mathrm{Ca}^{2+}$, it has been suggested that oxidants can enter the cytosol upon disruption of the PM [81]. A transient localized increase of ROS at the injury site has been found to facilitate repair [120] by activating specific proteins involved in vesicle fusion [85] and cytoskeletal remodeling [121]. A prolonged general state of oxidative stress however, prevents PM repair, and this can be mitigated by the addition of antioxidants. This was documented for skeletal muscle cells [122, 123], as well as for Chinese hamster ovary cells, which upon electroporation experience a sharp increase in oxidative species [124]. Likewise, increased levels of intracellular ROS were detected after picosecond irradiation of $200 \mathrm{~nm}$ spherical AuNPs, which scaled with laser fluence and lasted for min after photoporation [125]. Since ROS are very short lived, such sustained increases in intracellular ROS are more likely triggered by release from endogenous compartments, such as damaged or dysfunctional mitochondria [126].

Several other molecules and ions translocate during PM permeabilization. For instance, a decrease in intracellular $\mathrm{K}^{+}$levels has been reported in cells injured by different PFTs [110, 127]. However, the effects of such fluxes have not yet been investigated in the context of physical membrane disruption techniques. 


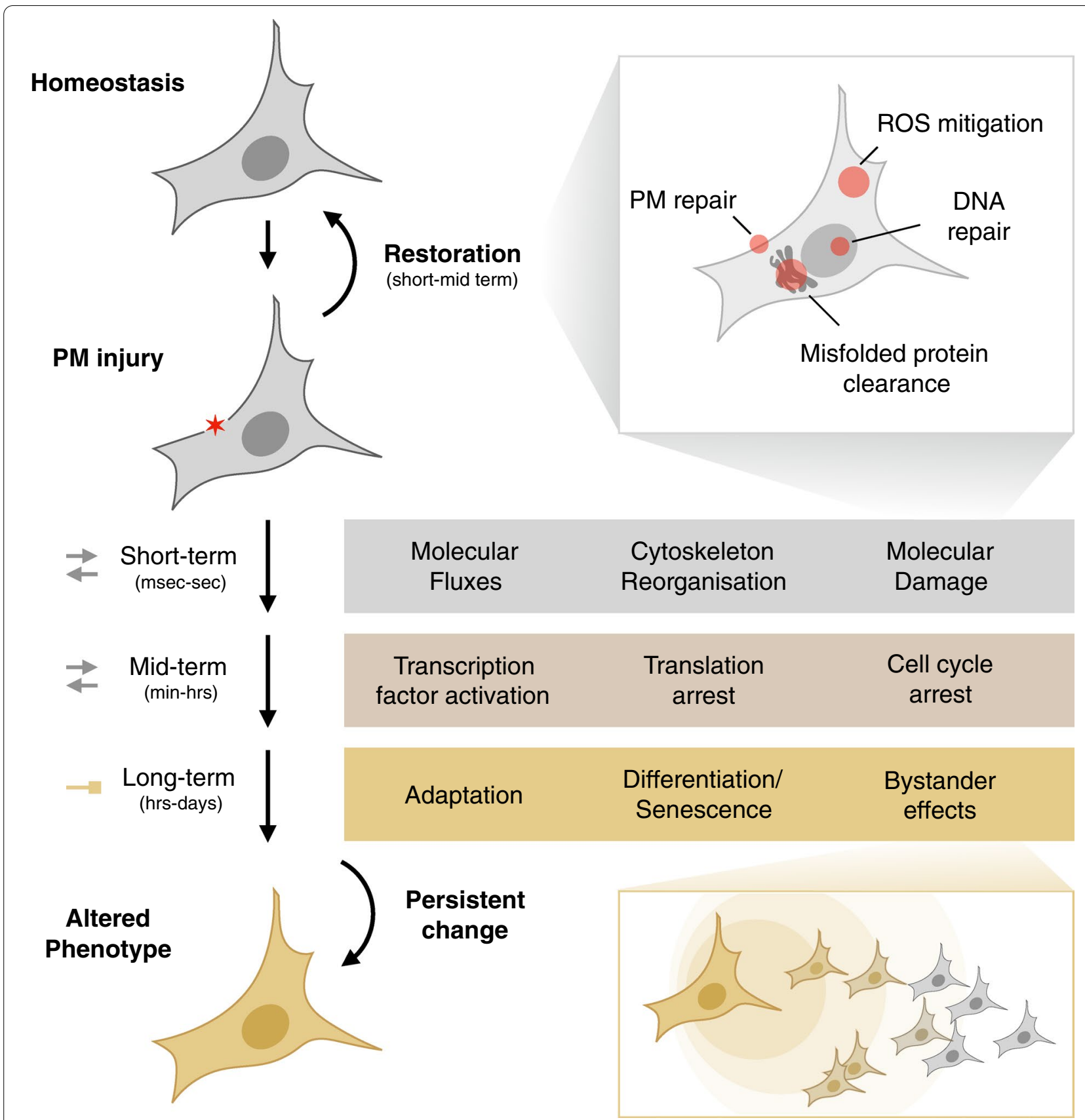

Fig. 3 Schematic overview of the different levels and aspects of the cellular response to PM injury. A detailed explanation of the responses can be found in the main text

Once the PM is resealed, the cell will try to restore its intracellular ion levels. Whereas intracellular $\mathrm{Ca}^{2+}$ has a vital role in repair of the PM and underlying cytoskeleton, excessive intracellular $\mathrm{Ca}^{2+}$ levels inhibit effective PM repair [128] and cause cell death [129, 130]. To avoid this, the cell rapidly lowers intracellular $\mathrm{Ca}^{2+}$ levels using cytosolic chelators [131] and ion pumps [132]. The SarcoEndoplasmic Reticulum Calcium ATPase
(SERCA) pumps $\mathrm{Ca}^{2+}$ back into the lumen of the ER [133], and the mitochondrial uniporter MCU-1 facilitates its uptake by mitochondria [134]. Generally, cytosolic $\mathrm{Ca}^{2+}$ levels are restored within minutes after PM disruption $[117,119]$. The increase in cytosolic $\mathrm{Ca}^{2+} \mathrm{In}$ $\mathrm{CD} 4+\mathrm{T}$-cells however, cytosolic $\mathrm{Ca}^{2+}$ has been found to peak only at $60 \mathrm{~min}$ post-nucleofection, before gradually returning to normal levels after $8 \mathrm{~h}$ [64]. 


\subsection{Cytoskeletal remodeling}

Upon PM disruption, the underlying actin cytoskeleton disintegrates rapidly [92, 135], which is thought to be induced by the rapid increase in intracellular $\mathrm{Ca}^{2+}$ levels [136]. Ultrasound-microbubble cavitation of the PM has been shown to induce a disruption of the filamentous F-actin network adjacent to the perforation site [137]. Cytoskeletal damage was also reported when treating cells with nanosecond pulsed electric fields [138], but this electroporation regimen is typically used to kill cells such as for the treatment of tumors [139] and thus reflects a condition that is incompatible with cell recovery.

Whereas cortical actin is initially depolymerized upon PM rupture, this is rapidly followed by accumulation of F-actin at the injury site [140]. Repolymerization of F-actin at the injury site is thought to aid in vesicle trafficking [141, 142] and in membrane repair [143-145] and provides structural support to the newly resealed membrane. In sonoporated cells however, the depolymerization of actin fibers was found to further propagate to other parts of the actin cytoskeleton during $60 \mathrm{~min}$ and resulted in a granular texture of the actin contents without preferential orientation [137]. One minute after PM pore formation by AuNP-mediated photoporation, a loss in coherency of F-actin fibers was observed, that further decreased $8 \mathrm{~min}$ after laser irradiation [146]. This was sometimes found to be accompanied by the formation of membrane blebs. A similar loss in the coherency of F-actin fiber orientation was observed immediately after photoporation of myoblasts grown on a plasmonic pyramid array.

Disassembly of microtubules (MTs) after membrane disruption has also been reported when cells were injured with a glass needle [147] and after sonoporationinduced membrane permeabilization [148]. Within $30 \mathrm{~s}$ after membrane disruption however, MTs start to reassemble and approach the injury site by elongation [147]. This is important to allow trafficking of lipids from the trans-Golgi network towards the injury site, which was found to be even more important for membrane resealing when a second insult at the same site was given [147]. The MT network appeared to be fully recovered in most cells within $60 \mathrm{~min}$.

An unexpected recent finding after nanoparticle-sensitized photoporation was a transient upregulation of A-type lamins [149]. Given a concomitant increase in chromatin condensation, this may reflect a global stiffening of the nucleus. Since the loss of A-type lamins sensitized cells to photoporation, the temporary upregulation may aid cells in their recovery from the insult. Interestingly, the upregulation was also observed after cell squeezing and electroporation [52] suggesting it is a generic response to physical PM injury.

\subsection{Morphological changes}

Upon permeabilization of the PM, changes in the volume of the entire cell and the nucleus have been observed [7, 150]. However, the functional relevance of these changes remains elusive. Swelling or shrinkage may simply reflect a response of the cell trying to counter the osmotic imbalances that were generated through the uncontrolled fluxes of ions and molecules between the cytosol and the extracellular environment during PM injury. Yet, these changes in morphology could trigger mechano-sensitive signal transduction pathways that alter gene expression (see further).

Cell shrinkage was reported to occur within minutes after PM pore formation with several optical permeabilization techniques, including optoporation [150], photoporation with cell-attached plasmonic particles [146] or photoporation with plasmonic substrates [151]. In the case of photoporation of cells with plasmonic substrates, cell shrinkage continued up until $60 \mathrm{~min}$ after laser treatment. This decrease in cytoplasm area was accompanied by a decrease in nuclear area, which stabilized after $30 \mathrm{~min}$. Cell swelling was reported for CD4 T-cells subjected to nucleofection with a dramatic expansion in cell size, while the size of the nucleus remained unchanged [7]. Here, it took about one hour for cell morphology to be restored, which corresponds with the time required for effective $\mathrm{Ca}^{2+}$ clearance to start [7]. PM poration of myoblasts by optoporation was also shown to induce shrinkage of nuclei and their retraction from the photoporation site [150]. The reorganization of the cytoskeleton upon PM disruption may be directly responsible for changes in nuclear shape and position, as it directly transmits mechanical force to the nucleus via the linker of nucleoskeleton to cytoskeleton (LINC) complex [152]. Shrinkage of both the cell and the nucleus has also been observed in response to sonoporation [108], but this both in cells that were successfully sonoporated and those that were not, suggesting that it may be induced by cavitational forces alone [108].

\section{Collateral damage may freeze the cell cycle to allow repair}

\subsection{ROS-induced damage}

ROS evoke various stress responses required for cell survival, but-when excessive or persistent-they can also have detrimental effects on cell homeostasis. ROSinduced oxidation of intracellular constituents may cause irreversible damage to all biomolecules. In response to shear stress from bubble oscillation, the level of intracellular $\mathrm{H}_{2} \mathrm{O}_{2}$ markedly increases during $1 \mathrm{~h}$ after exposure to ultrasound [118]. Surprisingly, removal of intracellular $\mathrm{H}_{2} \mathrm{O}_{2}$ via the addition of catalase blocked PM permeabilization altogether, suggesting it is a driving factor for 
successful poration [118]. In fibroblasts cultured on long nanowires, a higher ROS load and DNA damage level were observed, which were attributed to increased respiration rates [153]. Certain combinations of field strength and capacitance of electroporation pulses, also resulted in DNA damage in HL60 cells, although it is not clear whether it is driven by ROS [154].

\subsection{ER stress and translational halt}

In sonoporated cells, a loss of endoplasmic reticulum (ER) mass was observed over a time period of $6 \mathrm{~h}$ postsonoporation, which may reflect ER dysfunction. Simultaneously, various ER chaperones were upregulated $[155,156]$. An upregulation of the ER chaperone HSPA8 was also observed in cortical neural stem cells cultured on nanowire arrays [157], and a set of heat-shock protein encoding genes was found upregulated after nanoparticle-sensitized photoporation [149]. Upregulation of ER chaperones is part of the unfolded protein response (UPR), which is typically induced upon detection of unfolded proteins in the ER and which tries to restore ER homeostasis through various mechanisms. In response to PFTs, activation of the UPR is also observed, but there, it may reflect a response to pathogenic material, rather than an effect of PM disruption [110, 158]. Next to increasing the ER-folding capacity, UPR tries to restore ER homeostasis by limiting the amount of protein that enters. Reduction of global protein synthesis in UPR occurs via the PERK-facilitated phosphorylation of eIF2 $\alpha$ [159]. Nucleofection was found to induce this pathway [111], suggesting it triggers ER stress. A transient arrest in protein synthesis was also observed in response to two different PFTs, proaerolysin and listeriolysin, but this was found to be independent of UPR since arrest in protein synthesis was sustained upon silencing of PERK [110].

\subsection{Cell cycle stalling}

Molecular imbalance or damage may provoke cell cycle arrest. A delay in cell cycle progression is frequently observed in the viable population of various cell types after sonoporation [108, 109]. A concomitant dysregulation was found in the expression of various cyclin and cyclin-dependent kinase checkpoint proteins that are important for cell-cycle progression [109]. The observed accumulation of cells in the G2-M phase was however temporary [109], and cells resume cell cycle progression after some time. Proliferation of T-cells has been shown to be reduced when treated by electroporation for gene editing $[3,160]$. One possible reason for this proliferative stall could be DNA damage, but it was not assessed [161]. A delay in cell cycle progression does not seem to occur in response to different types of photoporation. VNB photoporation of Jurkat $\mathrm{T}$ cells using nanosecond pulsed irradiation of $60 \mathrm{~nm}$ spherical AuNPs showed unaltered proliferation rates up to 5 days post-transfection compared to untreated cells [3]. Primary human T cells and human embryonic stem cells (hESCs) treated with photothermal electrospun nanofibers (PEN photoporation) also did not suffer from a proliferative slowdown [6].

\section{Even long after restoration of PM injury the downstream effects can linger}

The various responses that are induced upon PM injury can trigger long-term alterations in cell fate and phenotype, fuelled by changes in gene expression. These may facilitate adaptation of the cells to the changing extracellular environment, which includes potentiation of injury repair mechanisms to recover faster from a potential second lesion and to increase resistance of the PM to a next insult. However, other less advantageous changes in cell phenotype can be triggered as well. This is a problem for engineered cell-based therapies where the therapeutic effect relies on phenotype-specific functionality.

\subsection{Persistent phenotype alterations}

Transcription of many genes is regulated directly via $\mathrm{Ca}^{2+}$ or indirectly via the $\mathrm{Ca}^{2+}$ sensor calmodulin [162-164]. Therefore, if cytosolic $\mathrm{Ca}^{2+}$ levels do not return to baseline once the membrane breach has been sealed, they may provoke transcriptional switches. Furthermore, gene expression programs can also be altered by changes in cell volume, as has been observed for different permeabilization techniques (vide supra). Cell proliferation for instance is stimulated by osmotic swelling and is inhibited in osmotically shrunken cells [165]. Regulated cell shrinkage and swelling is also required for cell motility [166] and a disturbed cell volume could therefore complicate cell movement. Cell shrinkage is also a ubiquitous hallmark of apoptosis, independent of the death stimulus [167, 168]. Recently it was found, however, that it is not the cell shrinkage itself, but the ion fluxes that cause cell shrinkage which induce apoptosis [169], implying that cell shrinkage alone does not necessarily lead to programmed cell death. The decrease in cytoplasmic volume is sometimes accompanied by a decrease in nuclear volume as well [170]. These changes in nuclear morphology may simply be the result of osmotic changes in the cells, but they may also be an active response to PM injury. Indeed, changes in nuclear morphology could also activate transcriptional programs to help the cell cope with the consequences of PM injury [171]. As heterochromatin is tethered to the nuclear envelope, changes in nuclear envelope geometry may induce gene expression through alterations in chromatin organization. Changes in gene expression may also be induced through the release of transcription factors that are normally sequestered at the nuclear periphery $[172,173]$. 
Recurrent phenotypic alterations involve activation and adhesion status. In the first $24 \mathrm{~h}$ after nucleofection, general transcriptional activity was significantly increased in CD4+T-cells, indicative of uncontrolled changes in activation status, making these cells no longer useful for studying the functions of naïve $\mathrm{T}$ cells [7]. Furthermore, a sustained increase of $\mathrm{T}$ cell activation markers CD154 and CD96 has been observed post-nucleofection [7]. Two independent reports also point to the loss of cell adhesion post-nucleofection. Astrocytes showed a reduced re-attachment to the substrate when re-plated after nucleofection [174]. Moreover, the most important differences in the proteome of quail oviduct epithelial cells after nucleofection were related to the absence of celladhesion proteins and keratins, indicative of reduced cell adhesion capabilities [8]. Cells cultured on vertical nanowire arrays on the other hand, showed upregulation of $\mathrm{CD}$ 9, an integral membrane protein that regulates cell adhesion, as well as upregulation of Rnd2, which is involved in the organization of the cortical cytoskeleton [157], and Kifap3, which is involved in microtubule-based processes [157]. Functional changes related to a loss in polarity have also been observed after nucleofection. The polarity of astrocytes is important for various functions, among which their wound healing response [175]. Upon scrape wounding in vitro, astrocytes polarize and extend protrusions towards the wound. Nucleofected astrocytes displayed a significantly reduced capacity to repopulate the scratched area compared to controls [174]. Finally, nucleofection has been reported to disrupt the fence function of tight junctions in renal epithelial cells, which is responsible for maintaining cell polarity [176]. This resulted in alteration of membrane polarity and mislocalization of transmembrane proteins [176].

Not all techniques however perturb cell homeostasis equally strong as electroporation does. Microfluidic squeezing of human T-cells has been shown to cause minimal aberrant transcriptional responses in contrast to electroporation [52]. Moreover, it was found that T-cells showed undiminished effector responses and homing capabilities after cell squeezing, indicating this technique does not affect T-cell functionality [52]. The impact of nanoparticle sensitized photoporation was found to be modest as well [149], and photoporation with photothermal nanofibers was shown to leave the differentiation potential of hESCs intact, as well as preserving $\mathrm{T}$ cell homeostasis and functionality in vitro and in vivo [6].

\subsection{Adaptive responses to PM injury}

Some of the persistent phenotypic changes may also arm cells for subsequent injury. Progress has been made in elucidating the signaling pathways that are required for adaptation to injury. Whereas PKC appears crucial for resealing an identical PM injury site, PKA activity is required for potentiation against injury at a different site [177-179]. Long-term potentiation of PM repair (24 h) requires cAMP response element (CRE)-mediated gene expression through $\mathrm{PKC}$ - and p38 mitogen-activated protein kinase (MAPK)-dependent pathways [180]. The events downstream of CRE-mediated gene expression that facilitate potentiation of injury-induced exocytosis remain to be elucidated. CREB mediates expression of immediate-early gene $c$-Fos [181] becomes upregulated in response to mechanical PM disruption in cell monolayers [182]. Inhibiting PM repair in osteocytes exacerbates $c$-Fos upregulation, while enhancing PM repair rate blunts it [183]. This indicates that at least in osteocytes, c-Fos upregulation through PM disruption represents a mechanosensory pathway that allows the bone to adapt to its mechanical environment. Whether $c$-Fos upregulation or that of any other immediate-early gene is required for potentiation of the response to injury, remains to be determined.

A mechano-adaptive response to PM injury has also been observed in circulating tumor cells. More specifically, exposure to fluid shear stress (FSS) induces small disruptions in the PM, which have been found to increase intravascular survival of these cells [184-186]. This increased resistance to membrane permeabilization requires activation of RhoA and actomyosin contractility [187]. What exactly triggers RhoA activation in response to the PM disruption caused by FSS has yet to be determined, but the fact that extracellular $\mathrm{Ca}^{2+}$ is essential for FSS resistance in cancer cells [184], suggests that $\mathrm{Ca}^{2+}$ influx could activate RhoA directly. It should be noted that membrane disruptions induced by FSS are small $(<12 \mathrm{~nm})$ [187] and it is unclear if the mechano-adaptation holds for larger ruptures as well.

\subsection{Long-term bystander effects of injured cells}

The response to PM injury is not limited to the injured cell itself. $\mathrm{Ca}^{2+}$ can spread to non-injured cells via gapjunctions $[188,189]$ or via extracellular agonists, such as ATP $[190,191]$, which trigger secondary release of $\mathrm{Ca}^{2+}$ from the lumen of the ER in adjacent cells. Wounding of cell monolayers initiates a $\mathrm{Ca}^{2+}$ wave that is propagated outwards from cells at the wound edge, which may prime those cells to proliferate during wound healing. Indeed, propagation of $\mathrm{Ca}^{2+}$ to cells further away has been shown to mediate preferential cell growth towards the wound edge [192]. Spreading of $\mathrm{Ca}^{2+}$ to adjacent cells may also be important to amplify the production of $\mathrm{H}_{2} \mathrm{O}_{2}$, which serves to attract immune cells to the wound to mount an adequate inflammatory response [193]. A delayed $\mathrm{Ca}^{2+}$ wave was for example observed in cells adjacent to sonoporated cells $[117,194] . \mathrm{Ca}^{2+}$ has been found to 
stimulate endocytosis in adjacent cells as well $[43,195]$, but the functional role thereof remains to be determined.

Via ATP signaling, neighboring cells are potentiated to induce a membrane repair response, without having the need for a previous insult $[196,197]$. This potentiation in other cells than the injured cell is also facilitated on the longer term, via the hydrophobic cell-permeable signaling molecule NO. Long term potentiation in neighboring cells requires CREB phosphorylation through activation of PKG activity [198].

\section{Conclusion and perspectives}

A breach in the PM instantly triggers an influx of $\mathrm{Ca}^{2+}$ and disruption of the cytoskeleton, which is often accompanied by changes in cell volume. Resealing of the pores occurs within minutes and the subsequent restoration of the PM both requires $\mathrm{Ca}^{2+}$ influx, cytoskeletal reorganization, and in some cases also localized ROS influx. Localized influx of $\mathrm{Ca}^{2+}$ and ROS at the injury site can be amplified through additional release from endogenous compartments to trigger additional signaling pathways. Excessive levels of intracellular $\mathrm{Ca}^{2+}$ should be removed, since these may disturb various intracellular processes required for normal cell functioning. Levels of intracellular ROS should also be controlled since these can damage various cellular components and perturb multiple pathways. To do so, cells may trigger a transient arrest in cell cycle progression and/or protein translation. Once cellular homeostasis is fully restored, these blocks will be lifted. When the cell does however not succeed to fully recover from the effects of PM injury, a permanent arrest in cell cycle (senescence) and even cell death may be triggered. Depending on the size and the type of PM disruption, the provoked long-term effects will differ, but some interesting similarities have been observed, such as the effect on cell adhesion. Most of the long-term changes of yet unknown functional relevance that are described here have been reported for nucleofection specifically. This is probably because exposing cells to strong electrical pulses can inflict damage to intracellular organelles as well, while the newer PM permeabilization techniques, which often make use of nanotechnology, are designed to limit damage mostly to the PM. As a result, these techniques are likely to have less impact on cell physiology. Nevertheless, further research is needed to understand shared and lasting consequences of PM injury, especially for these more recently developed nanotechnology-based methods. One major aspect is biocompatibility. Some technologies, like photoporation, make use of nanosensitizers that are brought in close contact with cells, and which can stay behind inside cells after treatment. Even though no obvious adverse effects have been reported on the short term, further research is warranted to determine any potential long-term effects of such nanoparticles on cells, especially if they are to be used for therapeutic purposes. Another area for further investigation is cell type-dependency. For, it is plausible that responses to and effects downstream of a membrane breach will differ between cell types based on their size, cycling behavior and molecular markup.

Detailed insight into the consequences of PM injury on cell physiology is especially important for genetic engineering of cells for therapeutic purposes. Indeed, in cell-based therapies and tissue engineering, the genetically modified cells should retain their full capacities in terms of function and proliferation to achieve successful treatment outcomes. Moreover, insight into the cellular response could be exploited to develop strategies to make pore formation easier, or to help the cell cope with the effects of PM injury and avoid unwanted side effects. Simple strategies that are already being used to promote repair consist of supplementing the buffer medium with antioxidants [122, 183] and calcium [15, 199]. The addition of polymers such as polyethyene glycol and poloxamers has been shown to promote membrane resealing as well [200-203], although the exact mechanisms remain to be elucidated. Another approach could consist of boosting the repair machinery directly, e.g., by providing the recombinant counterparts of proteins involved in membrane repair, such as annexins [84, 204, 205]. Next to assisting cells to seal the breach, another strategy to help cells manage PM injury is to prevent changes in cellular volume and composition, using a culture medium of a composition that resembles that of the intracellular fluid [206-208], although this might interfere with the actual repair.

Overall, strategies to help cells cope with PM injury beyond aiding in PM repair are currently limited. Significantly less attention has been given the specific pathways cells employ to cope with longer-lasting downstream effects of PM injury such as ER stress and cell cycle arrest. Exactly these pathways may be considered for combination treatments and for improving cell fitness after PM disruption. Future research could benefit from a more comprehensive analysis of these effects and their modulation, to obtain a holistic view on the cellular response to PM injury and to advance the field of PM disruption-mediated intracellular delivery.

\section{Abbreviations \\ AuNP: Gold nanoparticle; ER: Endoplasmic reticulum; FSS: Fluid shear stress; PEN: Photothermal electrospun nanofibers; PFT: Pore-forming toxin; PM:} Plasma membrane; ROS: Reactive oxygen species; VNB: Vapor nanobubble. 


\section{Authors' contributions}

GH wrote the initial manuscript; WDV and KB revised the manuscript. All authors read and approved the final manuscript.

\section{Funding}

This research was supported by the Research Foundation Flanders (FWO 1152918 N, FWO G005819N, FWO I003420N, FWO IRI I000321N and FWO $1210120 \mathrm{~N}$ ) and the University of Antwerp (BOF IMARK, $\mu$ NEURO).

\section{Availability of data and materials}

Not applicable.

\section{Declarations}

\section{Competing interests}

The authors declare that they have no competing interests.

\section{Author details}

${ }^{1}$ Laboratory of Cell Biology and Histology, Department of Veterinary Sciences, University of Antwerp, Antwerp, Belgium. ${ }^{2}$ Laboratory of General Biochemistry and Physical Pharmacy, Ghent University, Ghent, Belgium.

Received: 10 November 2021 Accepted: 5 January 2022

Published online: 01 February 2022

\section{References}

1. M.P. Stewart, R. Langer, K.F. Jensen, Intracellular delivery by membrane disruption: mechanisms strategies, and concepts. Chem. Rev. 118, 7409 (2018)

2. R. Xiong, K. Raemdonck, K. Peynshaert, I. Lentacker, I.D. Cock, J. Demeester, S.C.D. Smedt, A.G. Skirtach, K. Braeckmans, Comparison of gold nanoparticle mediated photoporation: vapor nanobubbles outperform direct heating for delivering macromolecules in live cells. ACS Nano 8, 6288 (2014)

3. L. Raes, S. Stremersch, J.C. Fraire, T. Brans, G. Goetgeluk, S.D. Munter, L.V. Hoecke, R. Verbeke, J.V. Hoeck, R. Xiong, X. Saelens, B. Vandekerckhove, S.D. Smedt, K. Raemdonck, K. Braeckmans, Intracellular delivery of MRNA in adherent and suspension cells by vapor nanobubble photoporation. Nanomicro. Lett. 12, 185 (2020)

4. R. Xiong, C. Drullion, P. Verstraelen, J. Demeester, A.G. Skirtach, C. Abbadie, W.H.D. Vos, S.C.D. Smedt, K. Braeckmans, Fast spatial-selective delivery into live cells. J. Control. Release 266, 198 (2017)

5. A. Harizaj, F.V. Hauwermeiren, S. Stremersch, R.D. Rycke, H.D. Keersmaecker, T. Brans, J.C. Fraire, K. Grauwen, S.C.D. Smedt, I. Lentacker, M. Lamkanfi, K. Braeckmans, Nanoparticle-sensitized photoporation enables inflammasome activation studies in targeted single cells. Nanoscale 13, $6592(2021)$

6. R. Xiong, D. Hua, J.V. Hoeck, D. Berdecka, L. Leger, S.D. Munter, J.C. Fraire, L. Raes, A. Harizaj, F. Sauvage, G. Goetgeluk, M. Pille, J. Aalders, J. Belza, T.V. Acker, E. Bolea-Fernandez, T. Si, F. Vanhaecke, W.H.D. Vos, B. Vandekerckhove, J. van Hengel, K. Raemdonck, C. Huang, S.C.D. Smedt, K. Braeckmans, Photothermal nanofibres enable safe engineering of therapeutic cells. Nat. Nanotechnol. 16, 1281 (2021)

7. M. Zhang, Z. Ma, N. Selliah, G. Weiss, A. Genin, T.H. Finkel, R.Q. Cron, The impact of nucleofection( $R$ ) on the activation state of primary human CD4 T cells. J. Immunol. Methods 408, 123 (2014)

8. K. Stadnicka, M. Debowska, J. Debski, A. Bajek, Secreting oviduct epithelial cells of coturnix Coturnix japonica (QOEC) and changes to their proteome after nonviral transfection. J. Cell. Biochem. 120, 12724 (2019)

9. F.C. Los, T.M. Randis, R.V. Aroian, A.J. Ratner, Role of pore-forming toxins in bacterial infectious diseases. Microbiol. Mol. Biol. Rev. 77, 173 (2013)

10. I. lacovache, M. Bischofberger, F.G. van der Goot, Structure and assembly of pore-forming proteins. Curr. Opin. Struct. Biol. 20, 241 (2010)

11. H. Ostolaza, D. Gonzalez-Bullon, K.B. Uribe, C. Martin, J. Amuategi, X. Fernandez-Martinez, Membrane permeabilization by pore-forming RTX toxins: what kind of lesions do these toxins form? Toxins $\mathbf{1 1}(6)$, 354 (2019). https://doi.org/10.3390/toxins11060354
12. E.M. Hotze, R.K. Tweten, Membrane assembly of the cholesteroldependent cytolysin pore complex. Biochim. Biophys. Acta 1818, 1028 (2012)

13. I. Walev, S.C. Bhakdi, F. Hofmann, N. Djonder, A. Valeva, K. Aktories, S. Bhakdi, Delivery of proteins into living cells by reversible membrane permeabilization with streptolysin-O. Proc. Natl. Acad. Sci. USA 98, 3185 (2001)

14. H.E. Rajapakse, N. Gahlaut, S. Mohandessi, D. Yu, J.R. Turner, L.W. Miller, Time-resolved luminescence resonance energy transfer imaging of protein-protein interactions in living cells. Proc. Natl. Acad. Sci. USA 107, 13582 (2010)

15. K.W. Teng, P. Ren, P.R. Selvin, Delivery of fluorescent probes using streptolysin o for fluorescence microscopy of living cells. Curr. Protoc. Protein Sci. 93, e60 (2018)

16. Y.T. Chow, S. Chen, R. Wang, C. Liu, C.W. Kong, R.A. Li, S.H. Cheng, D. Sun, Single cell transfection through precise microinjection with quantitatively controlled injection volumes. Sci. Rep. 6, 24127 (2016)

17. T. Hayashi, M. Nakajima, M. Kyakuno, K. Doi, I. Manabe, S. Azuma, T. Takeuchi, Advanced microinjection protocol for gene manipulation using the model newt Pleurodeles waltl. Int. J. Dev. Biol. 63, 281 (2019)

18. M.R. Capecchi, High efficiency transformation by direct microinjection of DNA into cultured mammalian cells. Cell 22, 479 (1980)

19. I. Obataya, C. Nakamura, S. Han, N. Nakamura, J. Miyake, Nanoscale operation of a living cell using an atomic force microscope with a nanoneedle. Nano Lett. 5, 27 (2005)

20. X.Xie, A.M. Xu, M.R. Angle, N. Tayebi, P. Verma, N.A. Melosh, Mechanical model of vertical nanowire cell penetration. Nano Lett. 13, 6002 (2013)

21. W. Kim, J.K. Ng, M.E. Kunitake, B.R. Conklin, P. Yang, Interfacing silicon nanowires with mammalian cells. J. Am. Chem. Soc. 129, 7228 (2007)

22. W. Zhao, L. Hanson, H.Y. Lou, M. Akamatsu, P.D. Chowdary, F. Santoro, J.R. Marks, A. Grassart, D.G. Drubin, Y. Cui, B. Cui, Nanoscale manipulation of membrane curvature for probing endocytosis in live cells. Nat. Nanotechnol. 12, 750 (2017)

23. S. Gopal, C. Chiappini, J. Penders, V. Leonardo, H. Seong, S. Rothery, Y. Korchev, A. Shevchuk, M.M. Stevens, Porous silicon nanoneedles modulate endocytosis to deliver biological payloads. Adv. Mater. 31, e1806788 (2019)

24. L. Schmiderer, A. Subramaniam, K. Zemaitis, A. Backstrom, D. Yudovich, S. Soboleva, R. Galeev, C.N. Prinz, J. Larsson, M. Hjort, Efficient and nontoxic biomolecule delivery to primary human hematopoietic stem cells using nanostraws. Proc. Natl. Acad. Sci. USA 117, 21267 (2020)

25. Y. Wang, Y. Yang, L. Yan, S.Y. Kwok, W. Li, Z. Wang, X. Zhu, G. Zhu, W. Zhang, X. Chen, P. Shi, Poking cells for efficient vector-free intracellular delivery. Nat. Commun. 5, 4466 (2014)

26. D. Magnin, V. Callegari, S. Matefi-Tempfli, M. Matefi-Tempfli, K. Glinel, A.M. Jonas, S. Demoustier-Champagne, Functionalization of magnetic nanowires by charged biopolymers. Biomacromol 9, 2517 (2008)

27. P. Sharma, H.A. Cho, J.W. Lee, W.S. Ham, B.C. Park, N.H. Cho, Y.K. Kim, Efficient intracellular delivery of biomacromolecules employing clusters of zinc oxide nanowires. Nanoscale 9, 15371 (2017)

28. A.M. Xu, D.S. Wang, P. Shieh, Y. Cao, N.A. Melosh, Direct Intracellular delivery of cell-impermeable probes of protein glycosylation by using nanostraws. ChemBioChem 18, 623 (2017)

29. B. Zhang, Y. Shi, D. Miyamoto, K. Nakazawa, T. Miyake, Nanostraw membrane stamping for direct delivery of molecules into adhesive cells. Sci. Rep. 9, 6806 (2019)

30. T.K. Wong, E. Neumann, Electric field mediated gene transfer. Biochem. Biophys. Res. Commun. 107, 584 (1982)

31. A. Paganin-Gioanni, E. Bellard, J.M. Escoffre, M.P. Rols, J. Teissie, M. Golzio, Direct visualization at the single-cell level of SiRNA electrotransfer into cancer cells. Proc. Natl. Acad. Sci. USA 108, 10443 (2011)

32. Q. Hu, R.P. Joshi, Transmembrane voltage analyses in spheroidal cells in response to an intense ultrashort electrical pulse. Phys. Rev. E Stat. Nonlin. Soft. Matter. Phys. 79, 11901 (2009)

33. J. Weiss, J. Garnon, D. Dalili, R.L. Cazzato, G. Koch, P. Auloge, A. Gangi, The feasibility of combined microwave ablation and irreversible electroporation for central liver metastase. Cardiovasc. Intervent. Radiol. 44, 999 (2021)

34. P.J. Canatella, J.F. Karr, J.A. Petros, M.R. Prausnitz, Quantitative study of electroporation-mediated molecular uptake and cell viability. Biophys. J. 80, 755 (2001) 
35. V.L. Sukhorukov, R. Reuss, D. Zimmermann, C. Held, K.J. Muller, M. Kiesel, P. Gessner, A. Steinbach, W.A. Schenk, E. Bamberg, U. Zimmermann, Surviving high-intensity field pulses: strategies for improving robustness and performance of electrotransfection and electrofusion. J. Membr. Biol. 206, 187 (2005)

36. M.L. Yarmush, A. Golberg, G. Sersa, T. Kotnik, D. Miklavcic, Electroporation-based technologies for medicine: principles applications, and challenges. Annu. Rev. Biomed. Eng. 16, 295 (2014)

37. T. Geng, C. Lu, Microfluidic electroporation for cellular analysis and delivery. Lab Chip 13, 3803 (2013)

38. K. Tachibana, T. Uchida, K. Ogawa, N. Yamashita, K. Tamura, Induction of cell-membrane porosity by ultrasound. Lancet 353, 1409 (1999)

39. A. van Wamel, K. Kooiman, M. Harteveld, M. Emmer, F.J. ten Cate, M. Versluis, N. de Jong, Vibrating microbubbles poking individual cells: drug transfer into cells via sonoporation. J. Control. Release 112, 149 (2006)

40. A. Delalande, S. Kotopoulis, M. Postema, P. Midoux, C. Pichon, Sonoporation: mechanistic insights and ongoing challenges for gene transfer. Gene 525, 191 (2013)

41. K. Tachibana, T. Uchida, S. Hisano, E. Morioka, Eliminating adult T-cell leukaemia cells with ultrasound. Lancet 349, 325 (1997)

42. M.M. Forbes, R.L. Steinberg, D.W. O'Brien Jr., Examination of inertial cavitation of optison in producing sonoporation of Chinese hamster ovary cells. Ultrasound Med. Biol. 34, 2009 (2008)

43. I. Lentacker, I.D. Cock, R. Deckers, S.C.D. Smedt, C.T. Moonen, Understanding ultrasound induced sonoporation: definitions and underlying mechanisms. Adv. Drug. Deliv. Rev. 72, 49 (2014)

44. Z. Fan, R.E. Kumon, C.X. Deng, Mechanisms of microbubble-facilitated sonoporation for drug and gene delivery. Ther. Deliv. 5, 467 (2014)

45. W.J. Greenleaf, M.E. Bolander, G. Sarkar, M.B. Goldring, J.F. Greenleaf, Artificial cavitation nuclei significantly enhance acoustically induced cell transfection. Ultrasound Med. Biol. 24, 587 (1998)

46. Y. Liu, J. Yan, M.R. Prausnitz, Can ultrasound enable efficient intracellular uptake of molecules? A retrospective literature review and analysis. Ultrasound Med. Biol. 38, 876 (2012)

47. M.A. Oberli, C.M. Schoellhammer, R. Langer, D. Blankschtein, Ultrasoundenhanced transdermal delivery: recent advances and future challenges. Ther. Deliv. 5, 843 (2014)

48. A. Sharei, J. Zoldan, A. Adamo, W.Y. Sim, N. Cho, E. Jackson, S. Mao, S. Schneider, M.J. Han, A. Lytton-Jean, P.A. Basto, S. Jhunjhunwala, J. Lee, D.A. Heller, J.W. Kang, G.C. Hartoularos, K.S. Kim, D.G. Anderson, R. Langer, K.F. Jensen, A vector-free microfluidic platform for intracellular delivery. Proc. Natl. Acad. Sci. USA 110, 2082 (2013)

49. J. Lee, A. Sharei, W.Y. Sim, A. Adamo, R. Langer, K.F. Jensen, M.G. Bawendi, Nonendocytic delivery of functional engineered nanoparticles into the cytoplasm of live cells using a novel high-throughput microfluidic device. Nano Lett. 12, 6322 (2012)

50. A. Sharei, R. Trifonova, S. Jhunjhunwala, G.C. Hartoularos, A.T. Eyerman, A. Lytton-Jean, M. Angin, S. Sharma, R. Poceviciute, S. Mao, M. Heimann, S. Liu, T. Talkar, O.F. Khan, M. Addo, U.H. von Andrian, D.G. Anderson, R. Langer, J. Lieberman, K.F. Jensen, Ex vivo cytosolic delivery of functional macromolecules to immune cells. PLoS ONE 10, e0118803 (2015)

51. A. Sharei, N. Cho, S. Mao, E. Jackson, R. Poceviciute, A. Adamo, J. Zoldan, R. Langer, K.F. Jensen, Cell squeezing as a robust, microfluidic intracellular delivery platform. J. Vis. Exp. 81, e50980 (2013). https://doi.org/10. $3791 / 50980$

52. T. DiTommaso, J.M. Cole, L. Cassereau, J.A. Bugge, J.L.S. Hanson, D.T. Bridgen, B.D. Stokes, S.M. Loughhead, B.A. Beutel, J.B. Gilbert, K. Nussbaum, A. Sorrentino, J. Toggweiler, T. Schmidt, G. Gyuelveszi, H. Bernstein, A. Sharei, Cell engineering with microfluidic squeezing preserves functionality of primary immune cells in vivo. Proc. Natl. Acad. Sci. 115, E10907 (2018)

53. M.T. Saung, A. Sharei, V.A. Adalsteinsson, N. Cho, T. Kamath, C. Ruiz, J. Kirkpatrick, N. Patel, M. Mino-Kenudson, S.P. Thayer, R. Langer, K.F. Jensen, A.S. Liss, J.C. Love, A size-selective intracellular delivery platform. Small 12, 5873 (2016)

54. Y. Deng, M. Kizer, M. Rada, J. Sage, X. Wang, D.J. Cheon, A.J. Chung, Intracellular delivery of nanomaterials via an inertial microfluidic cell hydroporator. Nano Lett. 18, 2705 (2018)

55. D. Stevenson, B. Agate, X. Tsampoula, P. Fischer, C.T. Brown, W. Sibbett, A. Riches, F. Gunn-Moore, K. Dholakia, Femtosecond optical transfection of cells: viability and efficiency. Opt. Express 14, 7125 (2006)
56. J. Baumgart, W. Bintig, A. Ngezahayo, S. Willenbrock, H.M. Escobar, W. Ertmer, H. Lubatschowski, A. Heisterkamp, Quantified femtosecond laser based opto-perforation of living GFSHR-17 and MTH53 a cells. Opt. Express 16, 3021 (2008)

57. A.A. Davis, M.J. Farrar, N. Nishimura, M.M. Jin, C.B. Schaffer, Optoporation and genetic manipulation of cells using femtosecond laser pulses. Biophys. J. 105, 862 (2013)

58. U.K. Tirlapur, K. Konig, Targeted transfection by femtosecond laser. Nature 418, 290 (2002)

59. C.P.Yao, Z.X. Zhang, R. Rahmanzadeh, G. Huettmann, Laser-based gene transfection and gene therapy. IEEE Trans. Nanobiosci. 7, 111 (2008)

60. M. Raab, M. Gentili, H. de Belly, H.R. Thiam, P. Vargas, A.J. Jimenez, F. Lautenschlaeger, R. Voituriez, A.M. Lennon-Dumenil, N. Manel, M. Piel, ESCRT III repairs nuclear envelope ruptures during cell migration to limit DNA damage and cell death. Sci. New York NY 352, 359 (2016)

61. D. Heinemann, S. Kalies, M. Schomaker, W. Ertmer, H.M. Escobar, H. Meyer, T. Ripken, Delivery of proteins to mammalian cells via gold nanoparticle mediated laser transfection. Nanotechnology 25, 245101 (2014)

62. J. Liu, R. Xiong, T. Brans, S. Lippens, E. Parthoens, F.C. Zanacchi, R. Magrassi, S.K. Singh, S. Kurungot, S. Szunerits, H. Bove, M. Ameloot, J.C. Fraire, E. Teirlinck, S.K. Samal, R. Rycke, G. Houthaeve, S.C.D. Smedt, R. Boukherroub, K. Braeckmans, Repeated photoporation with graphene quantum dots enables homogeneous labeling of live cells with extrinsic markers for fluorescence microscopy. Light Sci. Appl. 7, 47 (2018)

63. R. Xiong, S.K. Samal, J. Demeester, A.G. Skirtach, S.C.D. Smedt, K. Braeckmans, Laser-assisted photoporation: fundamentals technological advances and applications. Adv. Phys. X 1, 596 (2016)

64. A.S. Urban, M. Fedoruk, M.R. Horton, J.O. Radler, F.D. Stefani, J. Feldmann, Controlled nanometric phase transitions of phospholipid membranes by plasmonic heating of single gold nanoparticles. Nano Lett. 9, 2903 (2009)

65. D. Lapotko, Optical excitation and detection of vapor bubbles around plasmonic nanoparticles. Opt. Express 17, 2538 (2009)

66. R. Xiong, F. Joris, S. Liang, R.D. Rycke, S. Lippens, J. Demeester, A. Skirtach, K. Raemdonck, U. Himmelreich, S.C.D. Smedt, K. Braeckmans, Cytosolic delivery of nanolabels prevents their asymmetric inheritance and enables extended quantitative in vivo cell imaging. Nano Lett. 16, 5975 (2016)

67. L. Wayteck, R. Xiong, K. Braeckmans, S.C.D. Smedt, K. Raemdonck, Comparing photoporation and nucleofection for delivery of small interfering RNA to cytotoxic T cells. J. Control. Release 267, 154 (2017)

68. M. Schomaker, D. Heinemann, S. Kalies, S. Willenbrock, S. Wagner, I. Nolte, T. Ripken, H.M. Escobar, H. Meyer, A. Heisterkamp, Characterization of nanoparticle mediated laser transfection by femtosecond laser pulses for applications in molecular medicine. J. Nanobiotechnol. 13, 10 (2015)

69. E.Y. Lukianova-Hleb, D.S. Wagner, M.K. Brenner, D.O. Lapotko, Cellspecific transmembrane injection of molecular cargo with gold nanoparticle-generated transient plasmonic nanobubbles. Biomaterials 33, 5441 (2012)

70. T.S. Santra, S. Kar, T.C. Chen, C.W. Chen, J. Borana, M.C. Lee, F.G. Tseng, Near-infrared nanosecond-pulsed laser-activated highly efficient intracellular delivery mediated by nano-corrugated mushroom-shaped gold-coated polystyrene nanoparticles. Nanoscale 12, 12057 (2020)

71. L.V. Hoecke, L. Raes, S. Stremersch, T. Brans, J.C. Fraire, R. Roelandt, W. Declercq, P. Vandenabeele, K. Raemdonck, K. Braeckmans, X. Saelens, Delivery of mixed-lineage kinase domain-like protein by vapor nanobubble photoporation induces necroptotic-like cell death in tumor cells. Int. J. Mol. Sci. 20(17), 4254 (2019). https://doi.org/10.3390/ijms2 0174254

72. C. Yao, F. Rudnitzki, Y. He, Z. Zhang, G. Huttmann, R. Rahmanzadeh, Cancer cell-specific protein delivery by optoporation with laser-irradiated gold nanorods. J. Biophotonics 13, e202000017 (2020)

73. M. Schomaker, D. Killian, S. Willenbrock, D. Heinemann, S. Kalies, A. Ngezahayo, I. Nolte, T. Ripken, C. Junghanss, H. Meyer, H.M. Escobar, A. Heisterkamp, Biophysical effects in off-resonant gold nanoparticle mediated (GNOME) laser transfection of cell lines primary-and stem cells using Fs laser pulses. J. Biophotonics 8, 646 (2015)

74. G. Houthaeve, R. Xiong, J. Robijns, B. Luyckx, Y. Beulque, T. Brans, C. Campsteijn, S.K. Samal, S. Stremersch, S.C.D. Smedt, K. Braeckmans, 
W.H.D. Vos, Targeted perturbation of nuclear envelope integrity with vapor nanobubble-mediated photoporation. ACS Nano 12, 7791 (2018)

75. N. Saklayen, M. Huber, M. Madrid, V. Nuzzo, D.I. Vulis, W. Shen, J. Nelson, A.A. McClelland, A. Heisterkamp, E. Mazur, Intracellular delivery using nanosecond-laser excitation of large-area plasmonic substrates. ACS Nano 11, 3671 (2017)

76. Y.C. Wu, T.H. Wu, D.L. Clemens, B.Y. Lee, X. Wen, M.A. Horwitz, M.A. Teitell, P.Y. Chiou, Massively parallel delivery of large cargo into mammalian cells with light pulses. Nat. Methods 12, 439 (2015)

77. R. Xiong, D. Hua, J.V. Hoeck, D. Berdecka, L. Léger, S.D. Munter, J.C. Fraire, L. Raes, A. Harizaj, F. Sauvage, G. Goetgeluk, M. Pille, J. Aalders, J. Belza, T.V. Acker, E. Bolea-Fernandez, T. Si, F. Vanhaecke, W.H.D. Vos, B. Vandekerckhove, J. van Hengel, K. Raemdonck, C. Huang, S.C.D. Smedt, K. Braeckmans, Photothermal nanofibers enable safe engineering of therapeutic cells. Nat. Nanotechnol. 16, 1281 (2021)

78. D.E. Golan, M.R. Alecio, W.R. Veatch, R.R. Rando, Lateral mobility of phospholipid and cholesterol in the human erythrocyte membrane: effects of protein-lipid interactions. Biochemistry 23, 332 (1984)

79. N.L. Thompson, D. Axelrod, Reduced lateral mobility of a fluorescent lipid probe in cholesterol-depleted erythrocyte membrane. Biochim. Biophys. Acta 597, 155 (1980)

80. D.E. Ingber, N. Wang, D. Stamenovic, Tensegrity cellular biophysics, and the mechanics of living systems. Rep. Prog. Phys. 77, 46603 (2014)

81. A. Horn, J.K. Jaiswal, Cellular mechanisms and signals that coordinate plasma membrane repair. Cell Mol. Life. Sci. 75, 3751 (2018)

82. S.T. Cooper, P.L. McNeil, Membrane repair: mechanisms and pathophysiology. Physiol. Rev. 95, 1205 (2015)

83. N.W. Andrews, P.E. Almeida, M. Corrotte, Damage control: cellular mechanisms of plasma membrane repair. Trends Cell. Biol. 24, 734 (2014)

84. A. Bouter, C. Gounou, R. Berat, S. Tan, B. Gallois, T. Granier, B.L. d'Estaintot, E. Poschl, B. Brachvogel, A.R. Brisson, Annexin-A5 assembled into twodimensional arrays promotes cell membrane repair. Nat. Commun. 2, 270 (2011)

85. C. Cai, H. Masumiya, N. Weisleder, N. Matsuda, M. Nishi, M. Hwang, J.K. Ko, P. Lin, A. Thornton, X. Zhao, Z. Pan, S. Komazaki, M. Brotto, H. Takeshima, J. Ma, MG53 nucleates assembly of cell membrane repair machinery. Nat. Cell Biol. 11, 56 (2009)

86. T.L. Boye, K. Maeda, W. Pezeshkian, S.L. Sonder, S.C. Haeger, V. Gerke, A.C. Simonsen, J. Nylandsted, Annexin A4 and A6 induce membrane curvature and constriction during cell membrane repair. Nat. Commun. 8, $1623(2017)$

87. T.L. Boye, J.C. Jeppesen, K. Maeda, W. Pezeshkian, V. Solovyeva, J. Nylandsted, A.C. Simonsen, Annexins induce curvature on free-edge membranes displaying distinct morphologies. Sci. Rep. 8, 10309 (2018)

88. K. Miyake, P.L. McNeil, Vesicle accumulation and exocytosis at sites of plasma membrane disruption. J. Cell Biol. 131, 1737 (1995)

89. P.L. McNeil, S.S. Vogel, K. Miyake, M. Terasaki, Patching plasma membrane disruptions with cytoplasmic membrane. J. Cell Sci. 113(Pt 11), 1891 (2000)

90. R. Carmeille, F. Bouvet, S. Tan, C. Croissant, C. Gounou, K. Mamchaoui, V. Mouly, A.R. Brisson, A. Bouter, Membrane repair of human skeletal muscle cells requires annexin-A5. Biochim. Biophys. Acta 1863, 2267 (2016)

91. C.A. Mandato, W.M. Bement, Contraction and polymerization cooperate to assemble and close actomyosin rings around xenopus oocyte wounds. J. Cell Biol. 154, 785 (2001)

92. L.M. Godin, J.Vergen, Y.S. Prakash, R.E. Pagano, R.D. Hubmayr, Spatiotemporal dynamics of actin remodeling and endomembrane trafficking in alveolar epithelial type I cell wound healing. Am. J. Physiol. Lung Cell Mol. Physiol. 300, L615 (2011)

93. S.C. Hager, J. Nylandsted, Annexins: players of single cell wound healing and regeneration. Commun. Integr. Biol. 12, 162 (2019)

94. A.M. Moe, A.E. Golding, W.M. Bement, Cell healing: calcium, repair and regeneration. Semin. Cell Dev. Biol. 45, 18 (2015)

95. M. Corrotte, M.C. Fernandes, C. Tam, N.W. Andrews, Toxin pores endocytosed during plasma membrane repair traffic into the lumen of MVBs for degradation. Traffic 13, 483 (2012)

96. J. Thiery, D. Keefe, S. Saffarian, D. Martinvalet, M. Walch, E. Boucrot, T. Kirchhausen, J. Lieberman, Perforin activates clathrin- and dynamindependent endocytosis, which is required for plasma membrane repair and delivery of granzyme B for granzyme-mediated apoptosis. Blood $115,1582(2010)$

97. V. Idone, C. Tam, J.W. Goss, D. Toomre, M. Pypaert, N.W. Andrews, Repair of injured plasma membrane by rapid Ca2+-dependent endocytosis. J. Cell Biol. 180, 905 (2008)

98. A.J. Jimenez, P. Maiuri, J. Lafaurie-Janvore, S. Divoux, M. Piel, F. Perez, ESCRT machinery is required for plasma membrane repair. Science $\mathbf{3 4 3}$ 1247136 (2014)

99. A.P. Atanassoff, H. Wolfmeier, R. Schoenauer, A. Hostettler, A. Ring, A. Draeger, E.B. Babiychuk, Microvesicle shedding and lysosomal repair fulfill divergent cellular needs during the repair of streptolysin O-induced plasmalemmal damage. PloS ONE 9, e89743 (2014)

100. D. Keefe, L. Shi, S. Feske, R. Massol, F. Navarro, T. Kirchhausen, J. Lieberman, Perforin triggers a plasma membrane-repair response that facilitates CTL induction of apoptosis. Immunity 23, 249 (2005)

101. J. Hagmann, D. Dagan, M.M. Burger, Release of endosomal content induced by plasma membrane tension: video image intensification time lapse analysis. Exp. Cell Res. 198, 298 (1992)

102. J. Dai, H.P. Ting-Beall, M.P. Sheetz, The secretion-coupled endocytosis correlates with membrane tension changes in RBL $2 \mathrm{H} 3$ cells. J. Gen. Physiol 110, 1 (1997)

103. T. Togo, T.B. Krasieva, R.A. Steinhardt, A decrease in membrane tension precedes successful cell-membrane repair. Mol. Biol. Cell 11, 4339 (2000)

104. M. Nakamura, A.N.M. Dominguez, J.R. Decker, A.J. Hull, J.M. Verboon, S.M. Parkhurst, Into the breach: how cells cope with wounds. Open Biol. 8(10), 180135 (2018). https://doi.org/10.1098/rsob.180135

105. A.D. Blazek, B.J. Paleo, N. Weisleder, Plasma membrane repair: a central process for maintaining cellular homeostasis. Physiology 30, 438 (2015)

106. R. Baaske, M. Richter, N. Moller, S. Ziesemer, I. Eiffler, C. Muller, J.P. Hildebrandt, ATP release from human airway epithelial cells exposed to Staphylococcus aureus alpha-toxin. Toxins 8(12), 365 (2016). https://doi. org/10.3390/toxins8120365

107. M.P. Rols, J. Teissie, Electropermeabilization of mammalian cells quantitative analysis of the phenomenon. Biophys. J. 58, 1089 (1990)

108. X. Chen, J.M. Wan, A.C. Yu, Sonoporation as a cellular stress: induction of morphological repression and developmental delays. Ultrasound Med. Biol. 39, 1075 (2013)

109. W. Zhong, W.H. Sit, J.M. Wan, A.C. Yu, Sonoporation induces apoptosis and cell cycle arrest in human promyelocytic leukemia cells. Ultrasound Med. Biol. 37, 2149 (2011)

110. M.R. Gonzalez, M. Bischofberger, B. Freche, S. Ho, R.G. Parton, F.G. van der Goot, Pore-forming toxins induce multiple cellular responses promoting survival. Cell Microbiol. 13, 1026 (2011)

111. B.R. Anderson, K. Kariko, D. Weissman, Nucleofection induces transient EIF2alpha phosphorylation by GCN2 and PERK. Gene Ther. 20, 136 (2013)

112. P.L. McNeil, R.A. Steinhardt, Plasma membrane disruption: repair prevention, adaptation. Annu. Rev. Cell Dev. Biol. 19, 697 (2003)

113. C.S. Spaeth, E.A. Boydston, L.R. Figard, A. Zuzek, G.D. Bittner, A model for sealing plasmalemmal damage in neurons and other eukaryotic cells. J. Neurosci. 30, 15790 (2010)

114. X.Cheng, X. Zhang, Q. Gao, M.A. Samie, M. Azar, W.L. Tsang, L. Dong, N. Sahoo, X. Li, Y. Zhuo, A.G. Garrity, X. Wang, M. Ferrer, J. Dowling, L. Xu, R. Han, H. Xu, The intracellular $\mathrm{Ca}(2)(+)$ channel MCOLN1 is required for sarcolemma repair to prevent muscular dystrophy. Nat. Med. 20, 1187 (2014)

115. X.P. Dong, D. Shen, X. Wang, T. Dawson, X. Li, Q. Zhang, X. Cheng, Y. Zhang, L.S. Weisman, M. Delling, H. Xu, PI(3,5)P(2) controls membrane trafficking by direct activation of mucolipin $\mathrm{Ca}(2+)$ release channels in the endolysosome. Nat. Commun. 1, 38 (2010)

116. J. Baumgart, W. Bintig, A. Ngezahayo, H. Lubatschowski, A. Heisterkamp, Fs-laser-induced $\mathrm{Ca} 2+$ concentration change during membrane perforation for cell transfection. Opt. Express 18, 2219 (2010)

117. Z. Fan, R.E. Kumon, J. Park, C.X. Deng, Intracellular delivery and calcium transients generated in sonoporation facilitated by microbubbles. J. Control. Release 142, 31 (2010)

118. L.J. Juffermans, P.A. Dijkmans, R.J. Musters, C.A. Visser, O. Kamp, Transient permeabilization of cell membranes by ultrasound-exposed microbubbles is related to formation of hydrogen peroxide. Am. J. Physiol. Heart Circ. Physiol. 291, H1595 (2006) 
119. S. Johannsmeier, P. Heeger, M. Terakawa, S. Kalies, A. Heisterkamp, T. Ripken, D. Heinemann, Gold nanoparticle-mediated laser stimulation induces a complex stress response in neuronal cells. Sci. Rep. 8, 6533 (2018)

120. C.S. Spaeth, J.D. Fan, E.B. Spaeth, T. Robison, R.W. Wilcott, G.D. Bittner, Neurite transection produces cytosolic oxidation, which enhances plasmalemmal repair. J. Neurosci. Res. 90, 945 (2012)

121. A. Horn, J.H.V. der Meulen, A. Defour, M. Hogarth, S.C. Sreetama, A. Reed, L. Scheffer, N.S. Chandel, J.K. Jaiswal, Mitochondrial redox signaling enables repair of injured skeletal muscle cells. Sci. Signal. 10(495), eaaj1978 (2017). https://doi.org/10.1126/scisignal.aaj1978

122. A.C. Howard, A.K. McNeil, P.L. McNeil, Promotion of plasma membrane repair by vitamin E. Nat. Commun. 2, 597 (2011)

123. M. Labazi, A.K. McNeil, T. Kurtz, T.C. Lee, R.B. Pegg, J.P.F. Angeli, M. Conrad, P.L. McNeil, The antioxidant requirement for plasma membrane repair in skeletal muscle. Free Radic. Biol. Med. 84, 246 (2015)

124. B. Gabriel, J. Teissie, Generation of reactive-oxygen species induced by electropermeabilization of Chinese hamster ovary cells and their consequence on cell viability. Eur. J. Biochem. 223, 25 (1994)

125. S. Kalies, S. Keil, S. Sender, S.C. Hammer, G.C. Antonopoulos, M. Schomaker, T. Ripken, H.M. Escobar, H. Meyer, D. Heinemann, Characterization of the cellular response triggered by gold nanoparticlemediated laser manipulation. J. Biomed. Opt. 20, 115005 (2015)

126. V. Adler, Z. Yin, K.D. Tew, Z. Ronai, Role of redox potential and reactive oxygen species in stress signaling. Oncogene 18, 6104 (1999)

127. T. Wald, I. Petry-Podgorska, R. Fiser, T. Matousek, J. Dedina, R. Osicka, P. Sebo, J. Masin, Quantification of potassium levels in cells treated with bordetella adenylate cyclase toxin. Anal. Biochem. 450, 57 (2014)

128. E.B. Babiychuk, K. Monastyrskaya, S. Potez, A. Draeger, Intracellular $\mathrm{Ca}(2+)$ operates a switch between repair and lysis of streptolysin O-perforated cells. Cell Death Differ. 16, 1126 (2009)

129. G.E. Kass, S. Orrenius, Calcium signaling and cytotoxicity. Environ. Health Perspect. 107(Suppl 1), 25 (1999)

130. F.A. Schanne, A.B. Kane, E.E. Young, J.L. Farber, Calcium dependence of toxic cell death: a final common pathway. Science 206, 700 (1979)

131. B. Schwaller, Cytosolic Ca2+ buffers. Cold Spring Harb. Perspect. Biol. 2, a004051 (2010)

132. G. Chandra, S.C. Sreetama, D.A.G. Mazala, K. Charton, J.H. VanderMeulen, I. Richard, J.K. Jaiswal, Endoplasmic reticulum maintains ion homeostasis required for plasma membrane repair. J. Cell Biol. 220(5), e202006035 (2021). https://doi.org/10.1083/jcb.202006035

133. J.O. Primeau, G.P. Armanious, M.E. Fisher, H.S. Young, The sarcoendoplasmic reticulum calcium ATPase. Subcell. Biochem. 87, 229 (2018)

134. N.H. Tang, K.W. Kim, S. Xu, S.M. Blazie, B.A. Yee, G.W. Yeo, Y. Jin, A.D. Chisholm, The MRNA decay factor CAR-1/LSM14 regulates axon regeneration via mitochondrial calcium dynamics. Curr. Biol. 30, 865 (2020)

135. K. Miyake, P.L. McNeil, K. Suzuki, R. Tsunoda, N. Sugai, An actin barrier to resealing. J. Cell Sci. 114, 3487 (2001)

136. P.Wales, C.E. Schuberth, R. Aufschnaiter, J. Fels, I. Garcia-Aguilar, A. Janning, C.P. Dlugos, M. Schafer-Herte, C. Klingner, M. Walte, J. Kuhlmann, E. Menis, L.H. Kang, K.C. Maier, W. Hou, A. Russo, H.N. Higgs, H. Pavenstadt, T. Vogl, J. Roth, B. Qualmann, M.M. Kessels, D.E. Martin, B. Mulder, R. Wedlich-Soldner, Calcium-mediated actin reset (CaAR) mediates acute cell adaptations. Elife 5, e19850 (2016). https://doi.org/10.7554/eLife.19850

137. X. Chen, R.S. Leow, Y. Hu, J.M. Wan, A.C. Yu, Single-site sonoporation disrupts actin cytoskeleton organization. J. R. Soc. Interface 11, 20140071 (2014)

138. M. Stacey, P. Fox, S. Buescher, J. Kolb, Nanosecond pulsed electric field induced cytoskeleton, nuclear membrane and telomere damage adversely impact cell survival. Bioelectrochemistry 82,131 (2011)

139. C. Yao, J. Ning, H. Liu, Y. Lv, Y. Zhao, S. Dong, Nanosecond pulses targeting intracellular ablation increase destruction of tumor cells with irregular morphology. Bioelectrochemistry 132, 107432 (2020)

140. C. DeKraker, L. Goldin-Blais, E. Boucher, C.A. Mandato, Dynamics of actin polymerisation during the mammalian single-cell wound healing response. BMC Res. Notes 12, 420 (2019)

141. P. Li, A.T. Bademosi, J. Luo, F.A. Meunier, Actin remodeling in regulated exocytosis: toward a mesoscopic view. Trends Cell Biol. 28, 685 (2018)

142. D.T. Tran, A. Masedunskas, R. Weigert, K.G.T. Hagen, Arp2/3-mediated F-actin formation controls regulated exocytosis in vivo. Nat. Commun. 6, 10098 (2015)
143. A.R. Demonbreun, M. Quattrocelli, D.Y. Barefield, M.V. Allen, K.E. Swanson, E.M. McNally, An actin-dependent annexin complex mediates plasma membrane repair in muscle. J. Cell Biol. 213, 705 (2016)

144. J.K. Jaiswal, S.P. Lauritzen, L. Scheffer, M. Sakaguchi, J. Bunkenborg, S.M. Simon, T. Kallunki, M. Jaattela, J. Nylandsted, S100A11 is required for efficient plasma membrane repair and survival of invasive cancer cells. Nat. Commun. 5, 3795 (2014)

145. J.R. McDade, A. Archambeau, D.E. Michele, Rapid actin-cytoskeletondependent recruitment of plasma membrane-derived dysferlin at wounds is critical for muscle membrane repair. FASEB J. 28, 3660 (2014)

146. S. Kalies, G.C. Antonopoulos, M.S. Rakoski, D. Heinemann, M. Schomaker, T. Ripken, H. Meyer, Investigation of biophysical mechanisms in gold nanoparticle mediated laser manipulation of cells using a multimodal holographic and fluorescence imaging setup. PLoS ONE 10, e0124052 (2015)

147. T. Togo, Disruption of the plasma membrane stimulates rearrangement of microtubules and lipid traffic toward the wound site. J. Cell Sci. 119, 2780 (2006)

148. M. Wang, Y. Zhang, C. Cai, J. Tu, X. Guo, D. Zhang, Sonoporation-induced cell membrane permeabilization and cytoskeleton disassembly at varied acoustic and microbubble-cell parameters. Sci. Rep. 8, 3885 (2018)

149. G. Houthaeve, G.G.-D. Barriga, S. Stremersch, H.D. Keersmaecker, J. Fraire, J. Vandesompele, P. Mestdagh, S.D. Smedt, K. Braeckmans, W.H.D. Vos, Transient nuclear lamin A/C accretion aids in recovery from vapor nanobubble-induced permeabilization of the plasma membrane. Cell Mol. Life Sci. 79(1), 23 (2022). https://doi.org/10.1007/ s00018-021-04099-9

150. X. Duan, J.M.F. Wan, A.F.T. Mak, Oxidative stress alters the morphological responses of myoblasts to single-site membrane photoporation. Cell Mol. Bioeng. 10, 313 (2017)

151. N. Saklayen, S. Kalies, M. Madrid, V. Nuzzo, M. Huber, W. Shen, J. SinananSingh, D. Heinemann, A. Heisterkamp, E. Mazur, Analysis of porationinduced changes in cells from laser-activated plasmonic substrates. Biomed. Opt. Express 8, 4756 (2017)

152. T. Bouzid, E. Kim, B.D. Riehl, A.M. Esfahani, J. Rosenbohm, R. Yang, B. Duan, J.Y. Lim, The LINC complex, mechanotransduction, and mesenchymal stem cell function and fate. J. Biol. Eng. 13, 68 (2019)

153. H. Persson, C. Kobler, K. Molhave, L. Samuelson, J.O. Tegenfeldt, S. Oredsson, C.N. Prinz, Fibroblasts cultured on nanowires exhibit low motility impaired cell division, and DNA damage. Small 9, 4006 (2013)

154. W.S. Meaking, J. Edgerton, C.W. Wharton, R.A. Meldrum, Electroporationinduced damage in mammalian cell DNA. Biochim. Biophys. Acta 1264, 357 (1995)

155. W. Zhong, X. Chen, P. Jiang, J.M. Wan, P. Qin, A.C. Yu, Induction of endoplasmic reticulum stress by sonoporation: linkage to mitochondriamediated apoptosis initiation. Ultrasound Med. Biol. 39, 2382 (2013)

156. X. Duan, Q. Zhou, J.M.F. Wan, A.C.H. Yu, Sonoporation generates downstream cellular impact after membrane resealing. Sci. Rep. 11, 5161 (2021)

157. A. SanMartin, F. Johansson, L. Samuelson, C.N. Prinz, Microarray analysis reveals moderate gene expression changes in cortical neural stem cells cultured on nanowire arrays. J. Nanosci. Nanotechnol. 14, 4880 (2014)

158. L.J. Bischof, C.Y. Kao, F.C. Los, M.R. Gonzalez, Z. Shen, S.P. Briggs, F.G. van der Goot, R.V. Aroian, Activation of the unfolded protein response is required for defenses against bacterial pore-forming toxin in vivo. PLoS Pathog. 4, e1000176 (2008)

159. D. Ron, P. Walter, Signal integration in the endoplasmic reticulum unfolded protein response. Nat. Rev. Mol. Cell Biol. 8, 519 (2007)

160. J.D. Beane, G. Lee, Z. Zheng, M. Mendel, D. Abate-Daga, M. Bharathan, M. Black, N. Gandhi, Z. Yu, S. Chandran, M. Giedlin, D. Ando, J. Miller, D. Paschon, D. Guschin, E.J. Rebar, A. Reik, M.C. Holmes, P.D. Gregory, N.P. Restifo, S.A. Rosenberg, R.A. Morgan, S.A. Feldman, Clinical scale zinc finger nuclease-mediated gene editing of PD-1 in tumor infiltrating lymphocytes for the treatment of metastatic melanoma. Mol. Ther. 23, $1380(2015)$

161. H.X. Chao, C.E. Poovey, A.A. Privette, G.D. Grant, H.Y. Chao, J.G. Cook, J.E. Purvis, Orchestration of DNA damage checkpoint dynamics across the human cell cycle. Cell Syst. 5, 445 (2017)

162. S. Feske, J. Giltnane, R. Dolmetsch, L.M. Staudt, A. Rao, Gene regulation mediated by calcium signals in T lymphocytes. Nat. Immunol. 2, 316 (2001) 
163. M. Dewenter, A. von der Lieth, H.A. Katus, J. Backs, Calcium signaling and transcriptional regulation in cardiomyocytes. Circ. Res. 121, 1000 (2017)

164. M.J. Berridge, M.D. Bootman, H.L. Roderick, Calcium signalling: dynamics, homeostasis and remodelling. Nat. Rev. Mol. Cell Biol. 4, 517 (2003)

165. F. Lang, E. Shumilina, M. Ritter, E. Gulbins, A. Vereninov, S.M. Huber, lon channels and cell volume in regulation of cell proliferation and apoptotic cell death. Contrib. Nephrol. 152, 142 (2006)

166. E.K. Hoffmann, I.H. Lambert, S.F. Pedersen, Physiology of cell volume regulation in vertebrates. Physiol. Rev. 89, 193 (2009)

167. S. Elmore, Apoptosis: a review of programmed cell death. Toxicol. Pathol. 35, 495 (2007)

168. A. Saraste, K. Pulkki, Morphologic and biochemical hallmarks of apoptosis. Cardiovasc. Res. 45, 528 (2000)

169. C.D. Bortner, J.A. Cidlowski, Uncoupling cell shrinkage from apoptosis reveals that $\mathrm{Na}+$ influx is required for volume loss during programmed cell death. J. Biol. Chem. 278, 39176 (2003)

170. X. Duan, K.T. Chan, K.K. Lee, A.F. Mak, Oxidative stress and plasma membrane repair in single myoblasts after femtosecond laser photoporation. Ann. Biomed. Eng. 43, 2735 (2015)

171. M.F.A. Cutiongco, B.S. Jensen, P.M. Reynolds, N. Gadegaard, Predicting gene expression using morphological cell responses to nanotopography. Nat. Commun. 11, 1384 (2020)

172. S.M. Schreiner, P.K. Koo, Y. Zhao, S.G. Mochrie, M.C. King, The Tethering of chromatin to the nuclear envelope supports nuclear mechanics. Nat. Commun. 6, 7159 (2015)

173. B. van Steensel, A.S. Belmont, Lamina-associated domains: links with chromosome architecture heterochromatin, and gene repression. Cell 169,780 (2017)

174. H. Muyderman, W.P. Yew, B. Homkajorn, N.R. Sims, Astrocytic responses to dna delivery using nucleofection. Neurochem. Res. 35, 1771 (2010)

175. H. Peng, S. Carbonetto, Astrocyte polarization and wound healing in culture: studying cell adhesion molecules. Methods Mol. Biol. 814, 177 (2012)

176. D. Mo, B.A. Potter, C.A. Bertrand, J.D. Hildebrand, J.R. Bruns, O.A. Weisz, Nucleofection disrupts tight junction fence function to alter membrane polarity of renal epithelial cells. Am. J. Physiol. Renal. Physiol. 299, F1178 (2010)

177. T. Togo, J.M. Alderton, R.A. Steinhardt, Long-term potentiation of exocytosis and cell membrane repair in fibroblasts. Mol. Biol. Cell 14, 93 (2003)

178. T. Togo, J.M. Alderton, G.Q. Bi, R.A. Steinhardt, The mechanism of facilitated cell membrane resealing. J. Cell Sci. 112(Pt 5), 719 (1999)

179. S.S. Shen, R.A. Steinhardt, The mechanisms of cell membrane resealing in rabbit corneal epithelial cells. Curr. Eye Res. 30, 543 (2005)

180. T. Togo, Long-term potentiation of wound-induced exocytosis and plasma membrane repair is dependent on CAMP-response elementmediated transcription via a protein kinase C-and P38 MAPK-dependent pathway. J. Biol. Chem. 279, 44996 (2004)

181. P. Sassone-Corsi, J. Visvader, L. Ferland, P.L. Mellon, I.M. Verma, Induction of proto-oncogene fos transcription through the adenylate cyclase pathway: characterization of a CAMP-responsive element. Genes Dev. 2, 1529 (1988)

182. K.P. Grembowicz, D. Sprague, P.L. McNeil, Temporary disruption of the plasma membrane is required for C-Fos expression in response to mechanical stress. Mol. Biol. Cell 10, 1247 (1999)

183. K. Yu, D.P. Sellman, A. Bahraini, M.L. Hagan, A. Elsherbini, K.T. Vanpelt, P.L. Marshall, M.W. Hamrick, A. McNeil, P.L. McNeil, M.E. McGee-Lawrence, Mechanical loading disrupts osteocyte plasma membranes which initiates mechanosensation events in bone. J. Orthop. Res. 36, 653 (2018)

184. J.M. Barnes, J.T. Nauseef, M.D. Henry, Resistance to fluid shear stress is a conserved biophysical property of malignant cells. PLoS ONE 7, e50973 (2012)

185. M.J. Mitchell, C. Denais, M.F. Chan, Z. Wang, J. Lammerding, M.R. King, Lamin A/C deficiency reduces circulating tumor cell resistance to fluid shear stress. Am. J. Physiol. Cell Physiol. 309, C736 (2015)

186. U.L. Triantafillu, S. Park, N.L. Klaassen, A.D. Raddatz, Y. Kim, Fluid shear stress induces cancer stem cell-like phenotype in MCF7 breast cancer cell line without inducing epithelial to mesenchymal transition. Int. J. Oncol. 50, 993 (2017)
187. D.L. Moose B.L Krog, TH. Kim L. Zhao, S. Williams-Perez G. Burke L. Rhodes, M. Vanneste, P. Breheny, M. Milhem, C.S. Stipp, A.C. Rowat, M.D. Henry, Cancer cells resist mechanical destruction in circulation via RhoA/actomyosin-dependent mechano-adaptation. Cell Rep. 30, 3864 (2020)

188. K. Gao, C.R. Wang, F. Jiang, A.Y. Wong, N. Su, J.H. Jiang, R.C. Chai, G. Vatcher, J. Teng, J. Chen, Y.W. Jiang, A.C. Yu, Traumatic scratch injury in astrocytes triggers calcium influx to activate the JNK/C-Jun/AP-1 pathway and switch on GFAP expression. Glia 61, 2063 (2013)

189. C. Narciso, Q. Wu, P. Brodskiy, G. Garston, R. Baker, A. Fletcher, J. Zartman, Patterning of wound-induced intercellular $\mathrm{Ca}(2+)$ flashes in a developing epithelium. Phys. Biol. 12, 56005 (2015)

190. S. Shabir, J. Southgate, Calcium signalling in wound-responsive normal human urothelial cell monolayers. Cell Calcium 44, 453 (2008)

191. B. Huo, X.L. Lu, K.D. Costa, Q. Xu, X.E. Guo, An ATP-dependent mechanism mediates intercellular calcium signaling in bone cell network under single cell nanoindentation. Cell Calcium 47, 234 (2010)

192. Y.J. Sung, Z. Sung, C.L. Ho, M.T. Lin, J.S. Wang, S.C. Yang, Y.J. Chen, C.H. Lin, Intercellular calcium waves mediate preferential cell growth toward the wound edge in polarized hepatic cells. Exp. Cell. Res. 287, 209 (2003)

193. W. Razzell, I.R. Evans, P. Martin, W. Wood, Calcium flashes orchestrate the wound inflammatory response through DUOX activation and hydrogen peroxide release. Curr. Biol. 23, 424 (2013)

194. R.E. Kumon, M. Aehle, D. Sabens, P. Parikh, D. Kourennyi, C.X. Deng, Ultrasound-induced calcium oscillations and waves in chinese hamster ovary cells in the presence of microbubbles. Biophys. J. 93, L29 (2007)

195. S. Roovers, T. Segers, G. Lajoinie, J. Deprez, M. Versluis, S.C.D. Smedt, I. Lentacker, The role of ultrasound-driven microbubble dynamics in drug delivery: from microbubble fundamentals to clinical translation. Langmuir 35, 10173 (2019)

196. T. Togo, Short-term potentiation of membrane resealing in neighboring cells is mediated by purinergic signaling. Purinergic Signal. 10, 283 (2014)

197. T. Togo, Cell membrane disruption stimulates CAMP and $\mathrm{Ca}(2+)$ signaling to potentiate cell membrane resealing in neighboring cells. Biol. Open 6, 1814 (2017)

198. T. Togo, Cell membrane disruption stimulates NO/PKG signaling and potentiates cell membrane repair in neighboring cells. Plos ONE 7, e42885 (2012)

199. A. Sharei, R. Poceviciute, E.L. Jackson, N. Cho, S. Mao, G.C. Hartoularos, D.Y. Jang, S. Jhunjhunwala, A. Eyerman, T. Schoettle, R. Langer, K.F. Jensen, Plasma membrane recovery kinetics of a microfluidic intracelIular delivery platform. Integr. Biol. 6, 470 (2014)

200. S. Kouhzaei, I. Rad, K. Khodayari, H. Mobasheri, The neuroprotective ability of polyethylene glycol is affected by temperature in ex vivo spinal cord injury model. J. Membr. Biol. 246, 613 (2013)

201. R.C. Lee, L.P. River, F.S. Pan, L. Ji, R.L. Wollmann, Surfactant-induced sealing of electropermeabilized skeletal muscle membranes in vivo. Proc. Natl. Acad. Sci. USA 89, 4524 (1992)

202. J.M. Collins, F. Despa, R.C. Lee, Structural and functional recovery of electropermeabilized skeletal muscle in-vivo after treatment with surfactant poloxamer 188. Biochim. Biophys. Acta 1768, 1238 (2007)

203. T.A. Kwiatkowski, A.L. Rose, R. Jung, A. Capati, D. Hallak, R. Yan, N. Weisleder, Multiple poloxamers increase plasma membrane repair capacity in muscle and nonmuscle cells. Am. J. Physiol. Cell Physiol. 318, C253 (2020)

204. A.R. Demonbreun, K.S. Fallon, C.C. Oosterbaan, E. Bogdanovic, J.L. Warner, J.J. Sell, P.G. Page, M. Quattrocelli, D.Y. Barefield, E.M. McNally, Recombinant annexin A6 promotes membrane repair and protects against muscle injury. J. Clin. Invest. 129, 4657 (2019)

205. M.H. Kafshgari, L. Agiotis, I. Largilliere, S. Patskovsky, M. Meunier, Antibody-functionalized gold nanostar-mediated on-resonance picosecond laser optoporation for targeted delivery of RNA therapeutics. Small 17, e2007577 (2021)

206. M.J. van den Hoff, A.F. Moorman, W.H. Lamers, Electroporation in "intracellular" buffer increases cell survival. Nucleic Acids Res. 20, 2902 (1992)

207. F.V. Bockstaele, V. Pede, E. Naessens, S.V. Coppernolle, V.V. Tendeloo, B. Verhasselt, J. Philippe, Efficient gene transfer in CLL by MRNA electroporation. Leukemia 22, 323 (2008) 
208. S. Baron, J. Poast, D. Rizzo, E. McFarland, E. Kieff, Electroporation of antibodies, DNA, and other macromolecules into cells: a highly efficient method. J. Immunol. Methods 242, 115 (2000)

\section{Publisher's Note}

Springer Nature remains neutral with regard to jurisdictional claims in published maps and institutional affiliations.

\section{Submit your manuscript to a SpringerOpen ${ }^{\odot}$ journal and benefit from:}

- Convenient online submission

- Rigorous peer review

- Open access: articles freely available online

- High visibility within the field

- Retaining the copyright to your article

Submit your next manuscript at $\boldsymbol{\nabla}$ springeropen.com 